\title{
Antecedents of Effective Digital Leadership of Enterprises in Asia Pacific
}

\author{
Nanda Kumar Karippur \\ S P Jain School of Global Management, Singapore
}

Pushpa Rani Balaramachandran

S P Jain School of Global Management, Singapore

pushparani.b@spjain.org

\section{Abstract}

Increasing awareness of digital transformation across Asia Pacific is putting a strong spotlight on how enterprises think of leadership and related key practices. The pace of transition to the new digital organisation creates even larger leadership gaps as most organisations have not moved rapidly enough to develop relevant leadership practices. With the support of literature, an analysis of related theories of transformational leadership, ambidexterity and dynamic capabilities are examined and the most suitable leadership attributes and practices for a digital enterprise is proposed. We test the proposed research model via a sample of leaders and senior managers from the Asia Pacific region. The results highlight the significant roles of leadership attributes, strategic priorities, organisational focus areas for exploration and digital governance practices for exploitation, in influencing effective digital leadership. The article reports valuable insights and relevant implications for leaders, enterprises, and researchers.

Keywords: Ambidexterity, Digital leadership, Digital transformation, Digital governance, Dynamic capabilities, Transformational leadership.

\section{Introduction}

The current era of ubiquitous digital transformation affects most business organisations. Digital transformation involves leveraging emerging digital technologies such as mobile, cloud, data analytics, artificial intelligence, and Internet of things (IoT) technologies to enable business transformation and create new business models (Warner \& Wäger, 2019). It is about envisioning how organisations bring together people, data, and processes and provide valueadded services to their customers and sustain a competitive advantage in the digital world (Jimenez, Lim, Cheok, \& Ng, 2018). Digital enterprises are organisations that harness the power of latest digital technologies to improve business performance, recognize the need to be agile, search and rethink new business models, foster digital talent and adopt a collaborative approach and culture (Warner \& Wäger, 2019).

The focus of this study is digital transformation in the Asia Pacific region which is expected to accelerate over the next three years and the region is poised to receive the economic rewards. Asia Pacific's spending on tech was over US \$380 billion in 2019 (Huawei, 2020). With accelerated investment in digital transformation, International Data Corporation (2020) predicts over $65 \%$ of Asia Pacific Gross Domestic Product (GDP) will be digitalised and spending to hit US\$1.2 trillion between 2020 and 2023. The Asia Pacific region will account for over $50 \%$ of the global internet population and is expected to reach $72 \%$ of the regional population by 2023 (CISCO, 2020). The mobile internet user penetration in the region was at $48 \%$ in 2019 with over two billion mobile internet users and is forecasted to reach $61 \%$ in 2025 (Statista Research Department, 2021). Seizing the full gamut of digital opportunities, however, 
will require leadership commitment and dedication to a digital-first approach and a changed mindset that embraces collaboration, new skill acquisition and a rethinking of the manmachine relationship (Bahl, 2016; Tan, 2020).

Accelerating digital transformation in Asia Pacific is marked by enterprises' increasing initiatives to digitalize operations, empower employees, improve productivity, and engage customers (Jimenez et al., 2018). Over 43\% of nearly 600 respondents in the Asia Pacific region indicated digital transformation as their top priority (Tan, 2020). According to a 2018 Asia Pacific report (Jimenez et al., 2018), it is expected that by 2021, digital transformation will add $0.8 \%$ annually to Asia Pacific's GDP, or US\$1.16 trillion, with $60 \%$ of the region's GDP will be from digital products or services generated through digital transformation.

Jimenez et al. (2018) indicate that organisations can be categorised into two groups according to their digital transformation journeys; digital leaders and digital followers. Digital leaders have a clearer holistic vision, digital strategy and achieve higher returns from their digital transformation projects. Over 85\% of Asia Pacific organisations surveyed in 2017 (Jimenez et al., 2018) have embarked on their digital transformation journeys, of which, only $7 \%$ were classified as digital leaders. The study also showed that digital leaders reaped double the benefits of digital followers and identified five organisational traits of digital leaders; risktaking culture, flexibility and adaptability, collaboration with employees and partners, and alignment of organisation's strategies. With the increased awareness of digital transformation in Asia Pacific, there is a need to focus on factors influencing effective digital leadership.

Digital transformation requires competent leaders, who, with their knowledge and experience, would be able to drive the change to integrate technology and business organisations toward innovation and business transformation to achieve successful outcomes (Dahlström, Desmet, \& Singer, 2017; World Economic Forum, 2018). Organisations that are digital leaders strive to develop new digital capabilities and are making significant changes to their strategy-making process and organisational culture (Della Corte, Del Gaudio, \& Sepe, 2019). Leadership theory has been evolving from a modern, static leadership theory to increased recognition of the expansive resources and the organisational relationships involved in leadership practices (Raelin, 2016).

Digital enterprises require top to bottom organisational transformation (Sow \& Aborbie, 2018). Digital transformation is about competitiveness, new challenges, and innovation and how value can be created from digitalisation and establishing new ways of communication and collaboration (Oberer \& Erkollar, 2018). Hence, it is crucial for business leaders to adopt an effective leadership style and have the right capabilities to inspire their employees to innovate and sustain in the digital age.

This research focused on the following question: What are the antecedents of effective digital leadership of enterprises in Asia Pacific? Increasing awareness of digital transformation across Asia Pacific is putting a strong spotlight on how organisations think of leadership and related key practices. What is expected from successful leadership in the digital transformation era? There are significant research gaps in the areas of leadership attributes and practices leading to digital leadership. Successful digital transformation requires top management support and digital transformation is intrinsically cross-functional and will require new leadership practices to transform the organisation (Yokoi, Shan, Wade, \& Macaulay, 2019). The building of leadership capabilities for digital transformation has received limited scholarly attention (Warner \& Wäger, 2019). Not many empirical studies exist on leadership in the context of 
digital business transformation. However, organisational-change leadership is a widely researched topic with vast literature that provides many useful ideas on digital business transformation (Larjovuori, Bordi, \& Heikkilä-Tammi, 2018). The importance and scale of a digital transformation are so great that business leaders require to have certain attributes, capabilities, collaboration and support from top management and employees to effectively lead transformation successfully. This study focuses on the factors influencing effective leadership for digital enterprises such as leadership attributes, strategic priorities, organisational focus areas for exploration and digital governance practices.

Our research follows a quantitative approach with a strong empirical analysis to identify the key factors influencing effective leadership for digital enterprises. The next section will be a review of the related literature in order to develop a better understanding of the variables involved and their relation to the dependent variable. Section three will explain the proposed research model and hypotheses development for each of the identified variable, while section four will describe the data collection and analysis followed by section five on the discussion of the findings. Section six will elaborate on the implications for research and practice. Finally, the limitations, scope for future research and conclusion are stated at the end of the paper.

\section{Literature Review}

\subsection{Digital Enterprise}

A digital enterprise is an organisation that has a clear digital vision, high investment in digitalisation with focus on factors such as innovation culture, organisational agility, and nurturing talent to drive and deliver digital strategy (Della Corte et al., 2019). New digital organisations have evolved with the development of social media and mobile networking, big data, cloud computing and embracing of fourth industrial revolution (Bongiorno, Rizzo, \& Vaia, 2018). The most recent trends and directions of digital transformation are in the areas of Artificial Intelligence (AI) and Machine Learning (ML), Internet of Things (IoT), Analytics and Augmented Reality (AR). The technology industry is increasing its pace of implementing innovation, disruption and creating new ventures. Organisations across Asia Pacific need to catch up with technological advancements and plan as digitalisation becomes a top business priority. Companies across different sectors are converting their workplaces into digital workplaces (Cortellazzo, Bruni, \& Zampieri, 2019) by leveraging new technologies as an enabler of innovation, maximizing both the strategic and operational value and staying competitive in the dynamic business environment (Cascio \& Montealegre, 2016).

Organisations need to invest early in digital technologies, and this involves organisation-wide changes that pose significant challenges and uncertainties to business leaders. Digital transformation requires an organisation to set clear ambitious goals, have a digital vision and need capable leaders with innovative thinking and deep knowledge of the external market to drive the transformation and gain competitive advantage in the digital era (Bongiorno et al., 2018; Dahlström, Desmet, \& Singer, 2017). Digital transformation is challenging for organisations as they have to try to strike a balance in four main areas; building innovation capabilities along with existing product innovation, process and product innovations, collaboration between employees and external partners, and redesigning flexible and manageable governance structures (Svahn, Mathiassen, \& Lindgren, 2017). 


\subsection{Dynamic capabilities}

There is an interesting fit between digital transformation as a phenomenon of interest and dynamic capabilities as a conceptual foundation. The nature of digital transformation, as a source of continuous change and disruption, creates an impetus for organisations to adopt digital technologies to gain or maintain their competitive advantage (Vial, 2019). The dynamic capabilities framework helps to explain how enterprises respond to rapid technological and market change (Warner \& Wäger, 2019). Teece $(2007,2009)$ defines dynamic capabilities as an enterprises' ability to sense opportunities (and threats), seize opportunities, and transform or reconfigure the organisation's business model to adapt to the changing environment. With dynamic capabilities, an enterprise can sustain competitive advantage by leveraging and reconfiguring its existing competencies and assets to add value to its customers (O'Reilly III \& Tushman, 2011). However, there is limited research that examines how organisations build dynamic capabilities for digital transformation (Warner \& Wäger, 2019).

Organisations need to sense disruptions that enable continuous, repeatable adaptation to cope with rapid changes to the external competitive environment, seize strategic opportunities and reconfigure the business model to sustain competitiveness (Vial, 2019). Leadership capability is critical to achieve digital maturity, higher organisational performance and plays a role in building the dynamic capabilities of an organisation. Leaders need to sense the changes in market trends and prudently seize upon these trends by augmenting products with services and transforming the organisation. A digital leader takes on the role as a digital advisor with a clear vision, and ability to analyse environmental changes and disruptions of digital technologies and proactively reacts and invest resources to ensure the organisational transformation (Kane et al., 2017; Vial, 2019).

\subsection{Leadership in the digital age}

Digitally successful enterprises have built strong leadership capabilities to envisage and drive transformation (Zeike, Bradbury, Lindert, \& Pfaff, 2019). The role of leadership is crucial throughout the digital transformation journey of an organisation (Larjovuori et al., 2018). The demands of digital disruption entail new skills and leadership capabilities to improve processes, engage talent and develop new value-added business models for organisations (Kane et al., 2015). Leadership capabilities and the operationalisation and implementation of digitalisation are important factors for enterprises to succeed with digital transformation (Della Corte et al., 2019).

Digital transformation is creating new challenges for leaders (Cortellazzo et al., 2019). Rogers (2016) highlighted that senior leadership teams must develop new ideas to take advantage on new business model innovations that augment customer needs and experiences. Leaders must dexterously oscillate between long-term and short-term thinking, create trade-offs, and make decisions in imperfect situations quickly (Swift \& Lange, 2018). Leaders play a vital role to capitalise the value of digitalisation by retaining talent, engaging, and nurturing employees on the digital culture (Harvard Business Review, 2017; World Economic Forum, 2018). Leaders also need to be held accountable also for addressing new ethical concerns arising from the dark side of digital transformation such as unethical use of data. (Cortellazzo et al., 2019). Leader is a role figure who ensures digital maturity of an organisation with a digital vision and strategy (Sainger, 2018). The rapid changes associated with digital disruption can be disorienting and thus organisations require strong leaders at the helm (Kane, Phillips, Copulsky, \& Andrus, 2019). 
With digital leaders making significant changes to their organisational culture and strategy to lead a digital business, it is important that they communicate a clear vision to the people and provide a business environment to facilitate digital maturity (Della Corte et al., 2019). Digital leaders need to be creative visionaries and be prepared to accept and respond intuitively to continual disruption (Tardieu et al., 2020). Digital vision, empowerment, ability to manage diverse teams, are some of the competencies highlighted that are critical for digital transformation (Imran, Shahzad, Butt, \& Kantola, 2020).

Though there is extensive research stating that leadership plays an important role for achieving success in enterprise systems, there is lack of research on how specifically leadership achieves business success through the adoption of technology (Li et al., 2016). There are also very few studies that describe the impact of digital transformation on leadership (Cortellazzo et al., 2019).

\subsection{Theories of Leadership}

Leadership style is a combination of traits, skills, and behaviours that leaders practise as they interact with followers (Judge, Bono, Ilies, \& Gerhardt, 2002). There are various leadership theories such as behavioural leadership theories, leadership trait theories, and contingency leadership theories which explain the suitable leadership style based on the leader, followers, and organisational context (Oberer \& Erkollar, 2018).

Traditional leaders use power and influence to lead, are goal-oriented, authoritative, and decisive (Burley, 2019; Kane et al., 2019). However, they lack the innovation, collaboration with employees and agility. Hence, it is necessary to go beyond past leadership theories to explain the impact of digitalisation on leadership and leaders (Kahai, 2013). Some of the common characteristics of modern leadership theories include the role of social interaction and relational leadership practices (Larjovuori et al., 2018). Transactional and transformational leadership (Burns, 1978; Bass, 1985, 1990) are among the most influential behavioural leadership theories of the last decade (Diaz-Saenz, 2011).

Bass (1999) defined transformational leadership as motivating the follower beyond their selfinterest through inspiration, charisma, intellectual stimulation, or personalised consideration. Transformational leadership motivates followers by changing employees' values, manners, and behaviour, and, in turn, these followers propose new ideas and integrate such ideas into innovative activities. Transformative leaders have a positive influence on enterprises promoting creativity and explorative innovation (Kassotaki, 2019) and encourages employees to set and achieve their desired goals and put them into action to reach higher performance standards. In contrast, transactional leadership is task-oriented, uses various types of incentives to achieve goals and does not encourage experimentation or have positive influence on the organisation's creativity and more likely to be associated with exploitative innovation (Liu, $\mathrm{Yu}, \& \mathrm{Wu}, 2019$ ). The transactional leadership style focuses on completing tasks and ensuring employees follow the rules and pursues efficiency.

Organisations may employ leaders with different leadership styles; transformational leaders, who motivate others to be successful and empower creativity, and transactional leaders, who sets the tone for others to follow without providing many opportunities for creativity or innovation (Baškarada, Watson, \& Cromarty, 2016). In a study by Sow and Aborbie (2018), it was found that a transformational leadership style, to a certain extent, contributed to the desired outcomes during a digital transformation as compared to other leadership styles. A 
participative leadership style can involve employees in decision-making and induce positive outcomes for a successful change management strategy (Fatima, Majeed, \& Saeed, 2017).

Digital enterprises need transformative leaders with a vision for the future (Sow \& Aborbie, 2018), a cross-hierarchical, team-oriented, and collaborative approach, with a strong focus on innovation (Oberer \& Erkollar, 2018) and ability to embrace and drive change with a positive attitude (Vey, Fandel-Meyer, Zipp, \& Schneider, 2017). Current business leaders must be able to combine both traditional and new digital skills to effectively guide their organisations into the future (Kane et al., 2019) in order to stay competitive. Literature on leadership, in the context of digital transformation, is still in its infancy and not many empirical studies exist. For the purpose of this study, we have chosen to focus on transformational leadership as the characteristics closely suit the attributes and traits of a digital leader.

\subsection{Ambidextrous leadership}

Hess et al. (2020) report that firms in the current digital era face significant challenges despite the motivation and support by senior leadership for digital transformation. A major challenge is the need to balance the exploitation of existing capabilities while building new digital capabilities (Svahn, Mathiassen, \& Lindgren, 2017). Tushman and O'Reilly (1997) envisioned an ambidextrous organisation to be one where managers play two different roles simultaneously (Pearce, 2013).

Ambidexterity is characterised by leaders with the ability to exploit current resources to improve the business operations and concurrently take risks by exploring new opportunities and implement best practices to the existing business model (Finzi, Firth, \& Lipton, 2018).

Exploitation is based on the refinement, optimisation of resources, improvement in processes, competencies, and leveraging technologies for effective and efficient implementation (Popadiuk, Luz, \& Kretschmer, 2018). For example, in the context of digital transformation, there is a need to ensure that a secure infrastructure is available to fully exploit the speed and agility of the digital technology services (Heneghan, Snyder, \& Symons, 2017). Exploration refers to an organisation's move to take risks to experiment and discover new ideas, alternatives, search for new opportunities and adopt innovation (March, 1991). However, by relying only on exploration, an organisation may face problems such as the inability to capture returns on innovation (O'Reilly \& Tushman, 2008; O'Reilly \& Tushman, 2013). O'Reilly and Tushman (2004) found organisations exhibit ambidextrous characteristics when they seize exploratory and exploitative innovation in business units, strategically integrated yet structurally independent to the top management, for competitive advantage. For effective digitalisation, business units need to collaborate more effectively with firms across geographies and encourage employees to be active on platforms where they can collaborate on the development of cutting-edge technologies with experts in other organisations and provide them with opportunities to develop their digital skills (Kane et al., 2017; Finzi, Firth, \& Lipton, 2018; Cortellazzo et al., 2019).

Ambidextrous leadership comprise the dynamic capabilities of a leader to articulate a strategic vision, adapt, integrate, and reconfigure organisational skills, and explore and exploit resources to sustain in the changing business environments (O'Reilly III \& Tushman, 2011; Gentle \& Metselaar, 2020). Ambidextrous leaders can both build and run the business. Digital transformation is not just about digitising products and automating processes, it is also a new way of running the business. As customer expectations have changed, so must the approach 
to acquiring and serving those customers: faster, more transparent, more effortless, and more personalized. As such, ambidextrous leaders are able operate interchangeably between build and run disciplines and are equally skilled leading a development program as managing a commercial review. They can take a new business from idea to market; optimise every part of the value chain once launched; and at the same time evolve the product to narrow in on efficiencies or widen access and appeal. This comes from an understanding that in fast-moving and uncertain competitive markets, active iteration and innovation of the business model is required to survive and win (Takle, 2018). There is acknowledgement of an increased ambidexterity in the role of Chief Information Officers (CIOs) and their role as gatekeepers and contributors (Cortellazzo et al., 2019; Kohli \& Johnson, 2011).

\section{Research Model and Hypotheses}

This section discusses the proposed research model based on the literature surveyed in the previous section and drawing on the theories of transformational leadership, dynamic capabilities, and ambidexterity.

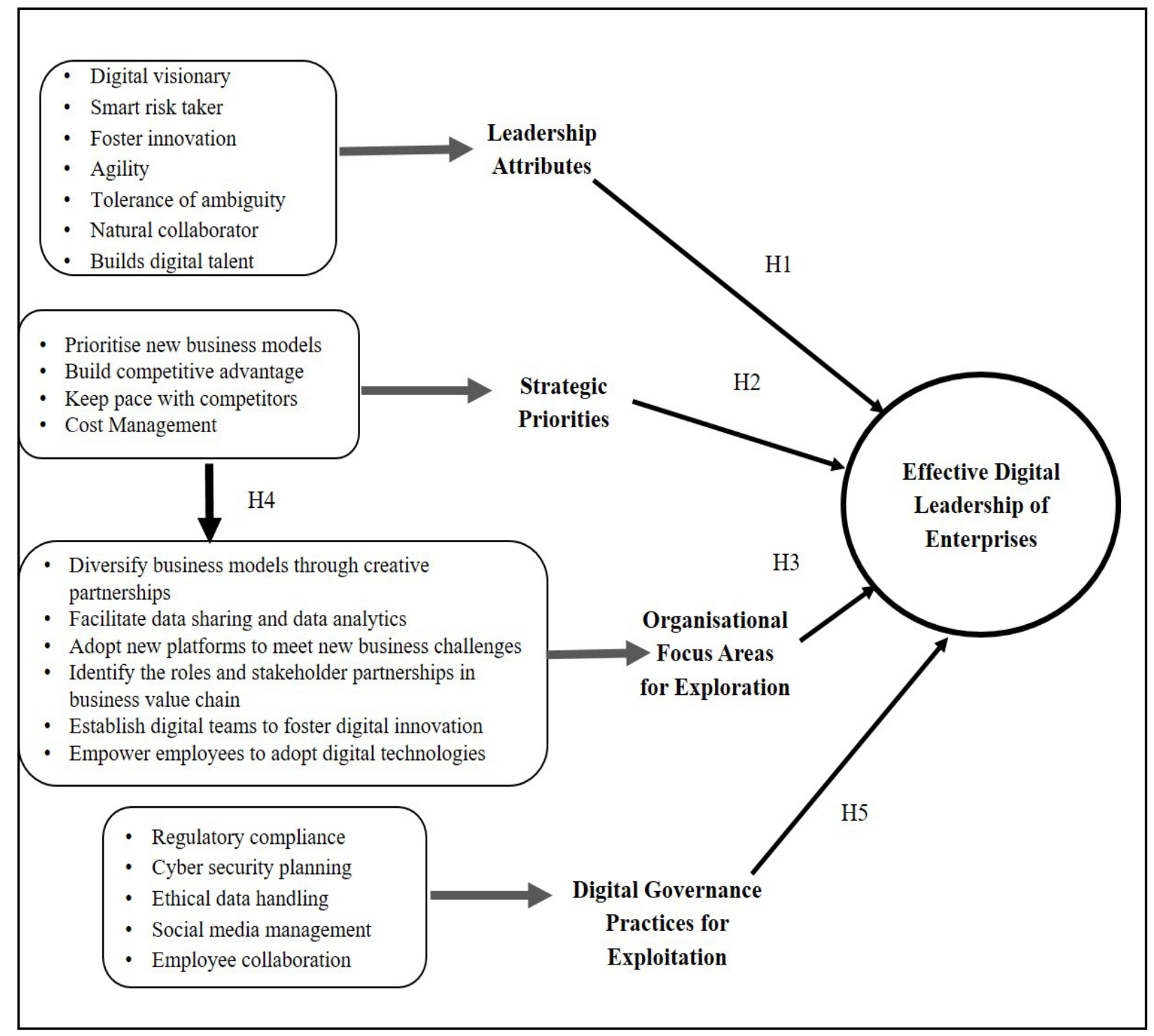

Figure 1. The Research Model 
Leadership attributes are critical traits of effective leadership in a digital environment (Kane et al., 2019; Kreutzer, Neugebauer, \& Pattloch, 2018). In ambidextrous leadership, leaders should not only be able to sense changes in their competitive environment but also potential changes in technology, customers, and competition (O'Reilly III \& Tushman, 2011) and set strategic priorities. Exploration is often linked with emerging customer needs, unexploited markets, harnessing new technologies and innovation. In order to support the new value creation opportunities of digital transformation, an effective combination of explorative and exploitative capability development is required. Leaders need to focus on a range of organisational areas for exploration (Havermans, Den Hartog, Keegan, \& Uhl-Bien, 2015). Digital Governance practices for exploitation play an important role in supporting organisational change, enables collaborative communications across organisational boundaries and a shared digital decision-making culture of an organisation (Bongiorno et al., 2018).

Figure 1 presents the proposed research model which theorises the role of these factors; leadership attributes, strategic priorities, organisational focus areas for exploration and digital governance practices for exploitation and simultaneously specifies the factors associated with them.

The following hypotheses are proposed and explained in the subsequent sections.

H1: The leadership attributes are positively associated with effective leadership for digital enterprises

H2: Strategic priorities of an organisation are positively associated with effective leadership for digital enterprises

H3: Organisational focus areas for exploration are positively associated with effective leadership for digital enterprises

H4: Strategic priorities are positively associated with organisational focus areas for exploration for digital enterprises

H5: Digital governance practices for exploitation is positively associated with effective leadership for digital enterprises

\subsection{Leadership Attributes}

Transformative vision, digital literacy and adaptability stand out as most critical traits of effective leadership in a digital environment (Kane et al., 2019; Kreutzer, Neugebauer, \& Pattloch, 2018). Leadership capabilities for digital enterprise involve creating a transformative digital vision, building technological leadership, engaging, and motivating employees and focusing on digital governance. (Westerman, Bonnet, \& McAfee, 2014a, 2014b).

Change-agile leaders must have a future vision and be adaptable to changes and fluctuations in the business world. Valentine and Steward (2015) indicated that the competencies of an effective digital leader should encompass skills, knowledge, and experience to govern technology for strategic advantage. In addition, digital leaders should be involved in making technology decisions, governing risk, and effectively using technology to reap returns and add value to the organisation. A summary of key leadership attributes critical to digital leadership is listed in Table 1 below. 


\begin{tabular}{|c|c|c|}
\hline $\begin{array}{l}\text { Leaderhip } \\
\text { Attributes }\end{array}$ & Description & References \\
\hline Digital visionary & $\begin{array}{l}\text { - Leaders' ability to create a vision that is clear and } \\
\text { meaningful for the organisation's digitalisation } \\
\text { process and have the capability to execute strategies } \\
\text { to actualize it } \\
\text { - Chief Executive Officer (CEO) must inspire } \\
\text { employees to pursue a vision of the company as a } \\
\text { digital business } \\
\text { Digital leaders need an innovative spirit and unique } \\
\text { ability to dream the big ideas }\end{array}$ & $\begin{array}{l}\text { Swift \& Lange, 2018.; } \\
\text { Larjovuori et al., 2018; } \\
\text { Neubauer, Tarling \& Wade, 2017; } \\
\text { Larjovuori, Bordi, \& Heikkilä- } \\
\text { Tammi, 2016; } \\
\text { El Sawy, Kræmmergaard, } \\
\text { Amsinck, \& Vinther, 2020; } \\
\text { Deloitte, } 2016\end{array}$ \\
\hline Smart risk taker & $\begin{array}{l}\text { - Leaders should open the door to new possibilities, } \\
\text { new markets, new customers and new innovations by } \\
\text { taking risks } \\
\text { - Leaders must be smart about managing risks }\end{array}$ & $\begin{array}{l}\text { Larjovuori et al., 2018; } \\
\text { Finzi, Firth, \& Lipton, 2018; } \\
\text { Swift \& Lange, } 2018\end{array}$ \\
\hline $\begin{array}{l}\text { Foster } \\
\text { innovation }\end{array}$ & $\begin{array}{l}\text { - Leaders needs to drive innovation to support digital } \\
\text { transformation and remain competitive } \\
\text { - Leaders need to cultivate an innovation culture } \\
\text { Leaders need to encourage employees to be creative, } \\
\text { collaborate and think out of the box to sustain } \\
\text { successfully as digital enterprises }\end{array}$ & $\begin{array}{l}\text { Kane et al., 2019; } \\
\text { Cortellazzo et al., 2019; } \\
\text { Dubey, 2019; } \\
\text { Larjovuori et al., 2018; } \\
\text { Swift \& Lange, 2018; } \\
\text { Heneghan, Snyder, \& Symons, } \\
2017\end{array}$ \\
\hline Agility & 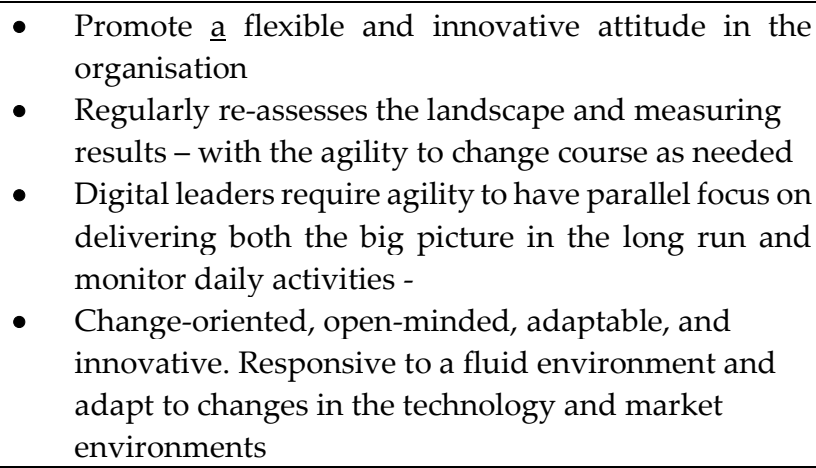 & $\begin{array}{l}\text { Hill, L.A., 2020; } \\
\text { Kane et al., 2019; } \\
\text { Cortellazzo et al., 2019; } \\
\text { Larjovuori et al., 2018; } \\
\text { Deloitte,2016; } \\
\text { Neubauer, Tarling \& Wade, 2017; } \\
\text { Heneghan, Snyder, \& Symons, } \\
2017\end{array}$ \\
\hline $\begin{array}{l}\text { Tolerance of } \\
\text { ambiguity }\end{array}$ & $\begin{array}{l}\text { - Leaders need to be aware of uncertain or ambiguous } \\
\text { information that prevents clarity of understanding or } \\
\text { direction } \\
\text { - Need to be an agile leader and be able to manage } \\
\text { uncertainty and ambiguity }\end{array}$ & $\begin{array}{l}\text { Cortellazzo et al., 2019; } \\
\text { Bongiorno et al., 2018; } \\
\text { Swift \& Lange, 2018; } \\
\text { Finzi, Firth, \& Lipton, } 2018\end{array}$ \\
\hline $\begin{array}{l}\text { Natural } \\
\text { collaborator }\end{array}$ & 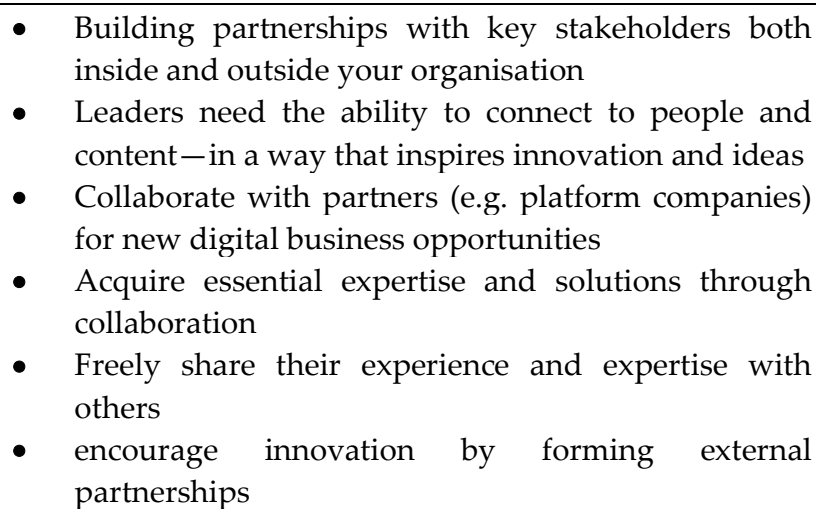 & $\begin{array}{l}\text { Hill, L. A., } 2020 \\
\text { Kane et al., 2019; } \\
\text { Cortellazzo et al., 2019; } \\
\text { Dubey 2019; } \\
\text { Larjovuori et al., } 2018\end{array}$ \\
\hline $\begin{array}{l}\text { Builds digital } \\
\text { talent }\end{array}$ & $\begin{array}{l}\text { - Leaders are expected to source the talent/skills } \\
\text { required to drive and deliver the digital strategy } \\
\text { Reskill existing employees and look at new ways to } \\
\text { expand the talent pool }\end{array}$ & $\begin{array}{l}\text { Larjovuori et al., 2018; } \\
\text { Finzi, Firth, \& Lipton, 2018; } \\
\text { Deloitte, 2016; } \\
\text { Geissbauer, Vedso, \& Schrauf, } \\
2016\end{array}$ \\
\hline
\end{tabular}




\begin{tabular}{|c|c|}
\hline & $\begin{array}{l}\text { - C-suite leaders will need to attract, retain, and train } \\
\text { other employees to work in a dynamic and digital } \\
\text { ecosystem environment } \\
\text { Encourage continuous learning, attract and retain } \\
\text { talent } \\
\text { - Motivating and inspiring employees to achieve } \\
\text { objectives of digitalisation }\end{array}$ \\
\hline
\end{tabular}

\section{Table 1. Leadership Attributes}

Hence, we hypothesise that the leadership attributes, as highlighted above, are positively associated with effective leadership for digital enterprises.

\subsection{Strategic Priorities}

The digital era has not only accelerated the pace of change but also opened wholly new opportunities for firms to embrace the technology and reinvent business models. (Hyek \& Nendick, 2014). Responding to the opportunities and threats of digital is challenging (Schadler et al., 2017) and each enterprise will need to prioritize its approach based on its unique market dynamics and relative digital maturity. Ambidexterity facilitates new resource configurations that can pose as a competitive advantage to the firm (Popadiuk et al., 2018). Leaders need to set strategic priorities related to marketing and investments to be made, thus requiring the creation or selection of business models (Popadiuk et al., 2018).

Ambidextrous leadership should be able to sense changes in their competitive environment, including possible shifts in technology, competition, customers (O'Reilly III \& Tushman, 2011) and set strategic priorities. The key strategic priorities for building a digital enterprise includes business model innovation, building competitive advantage, keeping pace with competitors and cost management (Gottlieb \& Willmott, 2014). A company's level of digital maturity has a significant influence on what the priorities of leaders should be (Tardieu et al., 2020). A summary of the key strategic priorities is listed in Table 2 below.

\begin{tabular}{|c|c|c|}
\hline Strategic Priority & Description & References \\
\hline $\begin{array}{l}\text { Prioritise new } \\
\text { business models }\end{array}$ & $\begin{array}{l}\text { - Create new business models, enhancing organisation's } \\
\text { adaptation capabilities to changing conditions and } \\
\text { business trends } \\
\text { - } \quad \text { Seek high-level priorities for the organisation } \\
\text { - Prioritize organisation's approach based on its unique } \\
\text { market dynamics and relative digital maturity. } \\
\text { - Identify the digital opportunity and understand the new } \\
\text { data-centric business paradigms }\end{array}$ & $\begin{array}{l}\text { Tardieu et al., 2020; } \\
\text { Popadiuk et al., 2018; } \\
\text { Schadler et al., 2017; } \\
\text { Hyek \& Nendick, } 2014\end{array}$ \\
\hline $\begin{array}{l}\text { Build competitive } \\
\text { advantage }\end{array}$ & $\begin{array}{l}\text { - Re-evaluate strategies, market position, competitive } \\
\text { strengths and strategic changes to remain successful } \\
\text { - } \quad \text { Review assets that give a potential competitive } \\
\text { advantage and fully leverage them in strategies }\end{array}$ & $\begin{array}{l}\text { Tardieu et al.,2020; } \\
\text { Popadiuk et al., 2018; } \\
\text { Hyek \& Nendick, } 2014\end{array}$ \\
\hline $\begin{array}{l}\text { Keep pace with } \\
\text { competitors }\end{array}$ & $\begin{array}{l}\text { - Observe the nature of competition and discover what } \\
\text { competitors are doing better and what can be learnt from } \\
\text { them. } \\
\text { - Keep pace with competitors through enhancing, } \\
\text { protecting, and reconfiguring the assets of the business } \\
\text { enterprise } \\
\text { Make thoughtful choices about adopting the right } \\
\text { technologies to innovate the businesses }\end{array}$ & $\begin{array}{l}\text { Donahue, } 2020 \\
\text { Popadiuk et al., 2018; } \\
\text { Deloitte, } 2017\end{array}$ \\
\hline Cost Management & $\begin{array}{l}\text { - Provide strategic lever to generate savings that can be } \\
\text { invested in driving growth, create new opportunities, }\end{array}$ & Ittner, 2019; \\
\hline
\end{tabular}




\begin{tabular}{|l|l|l|}
\hline & $\begin{array}{l}\text { and proactive ways to become more competitive in the } \\
\text { global environment }\end{array}$ & $\begin{array}{l}\text { Gottlieb, \& Willmott, } \\
\text { 2014; }\end{array}$ \\
& $\begin{array}{l}\text { Maintain cost control } \\
\text { - Minimising transaction / operating costs } \\
\text { - Leverage digital technologies for cost management }\end{array}$ & \\
\end{tabular}

Table 2. Strategic Priorities

Hence, we hypothesise that strategic priorities of an organisation, as highlighted above, are positively associated with effective leadership for digital enterprises.

\subsection{Organisational Focus Areas for Exploration}

Exploration is often linked with emerging customer needs, unexploited markets, harnessing new technologies and innovation. In order to support the new value creation opportunities of digital transformation, an effective combination of explorative and exploitative capability development is required. Leaders need to focus on a range of organisational areas for exploration (Havermans, Den Hartog, Keegan, \& Uhl-Bien, 2015). To execute a digital strategy, organisations need transforming capabilities, which includes the continuous strategic renewal of assets and organisational structures (Agarwal \& Helfat, 2009; Teece, 2014), to respond to the dynamic environment and realize the full potential of strategic change (Bharadwaj et al., 2013; Karimi \& Walter, 2015; Teece \& Linden, 2017).

Digital transformation uses platform technologies to create value and competitive advantage through offering new products and services, new business models, and new relationships (International Data Group, 2018). In order to transform their business to exploit the benefits of digitalisation, companies should focus on digital strategy, derive new business models, use data and analytics for decision-making and predicting future opportunities, adopt technology for operational efficiency, build an eco-system of partnerships, develop cross-functional talents and empower individuals and teams (World Economic Forum, 2018).

For this study, the key areas to focus in an organisation to achieve successful digital transformation include diversifying business models through creative partnerships (Fenwick \& Schadler, 2018), facilitate data sharing and data analytics (Geissbauer, Vedso, \& Schrauf, 2016; International Data Group, 2018), adopting new platforms to meet new business challenges (De la Boutetière, Montagner, \& Reich, 2018), identifying the roles and stakeholder partnership in business value chain, establishing digital teams to foster digital innovation (Geissbauer, Vedso, \& Schrauf, 2016) and empower employees to adopt digital technologies (Westerman et al., 2014a, 2014b; De la Boutetière et al., 2018). A summary of the organisational focus areas is listed in Table 3 below.

\begin{tabular}{|c|c|c|}
\hline $\begin{array}{l}\text { Organisational } \\
\text { Focus Areas for } \\
\text { Exploration }\end{array}$ & Description & References \\
\hline $\begin{array}{l}\text { Diversify business } \\
\text { models through } \\
\text { creative } \\
\text { partnerships }\end{array}$ & $\begin{array}{l}\text { - Compete in fast-changing digital environments by making } \\
\text { informed decisions about when to build, buy or partner to } \\
\text { develop solutions that can accelerate the organisation's own } \\
\text { digital transformation } \\
\text { - Find ways to capitalize on new and unexpected model } \\
\text { innovation that optimise customer needs and experiences } \\
\text { - Create, modify, significantly extend or replace the business } \\
\text { model of the enterprise through strategic partnerships and } \\
\text { alliances with businesses dealing with improved technology }\end{array}$ & $\begin{array}{l}\text { Knight, 2020; } \\
\text { Della Corte et al., } \\
2019 ; \\
\text { Fenwick \& } \\
\text { Schadler, 2018; } \\
\text { Hyek \& Nendick, } \\
2014\end{array}$ \\
\hline
\end{tabular}




\begin{tabular}{|c|c|c|}
\hline $\begin{array}{l}\text { Facilitate data } \\
\text { sharing and data } \\
\text { analytics }\end{array}$ & $\begin{array}{l}\text { - Capitalise on data sharing and data analytics to sense new } \\
\text { customer-centric trends and enhance strategic decision- } \\
\text { making } \\
\text { - Create a data-driven culture and accrue the competitive } \\
\text { benefits that result from it } \\
\text { - Use analytics to derive actionable insights, make effective } \\
\text { business decisions and add value to the business }\end{array}$ & $\begin{array}{l}\text { Davenport \& } \\
\text { Mittal, 2020; } \\
\text { International Data } \\
\text { Group, 2018; } \\
\text { Geissbauer, Vedso, } \\
\text { \& Schrauf, } 2016\end{array}$ \\
\hline $\begin{array}{l}\text { Adopt new } \\
\text { platforms to meet } \\
\text { new business } \\
\text { challenges }\end{array}$ & $\begin{array}{l}\text { - Adopt emerging technology platforms such as cloud for better } \\
\text { integration with business value chain partners, such as } \\
\text { suppliers and key customers, to improve efficiencies } \\
\text { significantly } \\
\text { - } \quad \text { Adopting disruptive technologies to improve the customer } \\
\text { experience and increase efficiency } \\
\text { - Collaborate with additional platform companies to jointly } \\
\text { explore potential innovations } \\
\text { - Leveraging these partnerships to increase innovation }\end{array}$ & $\begin{array}{l}\text { Finzi, Firth, \& } \\
\text { Lipton, 2018; } \\
\text { De la Boutetière et } \\
\text { al., } 2018\end{array}$ \\
\hline $\begin{array}{l}\text { Identify the roles } \\
\text { and stakeholder } \\
\text { partnership in } \\
\text { business value } \\
\text { chain }\end{array}$ & $\begin{array}{l}\text { - Digitalising essential functions within the internal operations } \\
\text { processes and with horizontal partners along the value chain } \\
\text { Integration into digital ecosystems with value chain partners } \\
\text { through end-to-end digitisation of all physical assets } \\
\text { - Collaborating and engaging with business stakeholders early } \\
\text { in the process builds innovation and creates value from } \\
\text { procurement }\end{array}$ & $\begin{array}{l}\text { Chee \& Young, } \\
\text { 2020; } \\
\text { Geissbauer, Vedso, } \\
\text { \& Schrauf, } 2016\end{array}$ \\
\hline $\begin{array}{l}\text { Establish digital } \\
\text { teams to foster } \\
\text { digital innovation }\end{array}$ & $\begin{array}{l}\text { - Setting up cross-functional teams to foster digital innovation } \\
\text { and accelerate digital transformation } \\
\text { - Allocate time for employees to experiment or innovate } \\
\text { - Build multi-disciplinary teams, foster collaboration across } \\
\text { departments, encourage brainstorming and shared decision } \\
\text { making }\end{array}$ & $\begin{array}{l}\text { Kane, 2019; } \\
\text { Link, 2018; } \\
\text { Geissbauer, Vedso, } \\
\text { \& Schrauf, } 2016\end{array}$ \\
\hline $\begin{array}{l}\text { Empower } \\
\text { employees to adopt } \\
\text { digital technologies }\end{array}$ & $\begin{array}{l}\text { - Giving employees the opportunity to generate their own ideas } \\
\text { and propose where digitisation / digital technologies could } \\
\text { and should be adopted in the business } \\
\text { Establishing practices related to empower employees to work } \\
\text { in new ways, play key roles in reinforcing changes and keep } \\
\text { pace with the fast business } \\
\text { Enabling and empowering employees to thrive in a digital } \\
\text { environment by providing them with the resources and } \\
\text { opportunities to carry out new initiatives }\end{array}$ & $\begin{array}{l}\text { Kane et al., 2019; } \\
\text { De la Boutetière et } \\
\text { al., 2018; } \\
\text { Westerman et al., } \\
2014 a, 2014 b\end{array}$ \\
\hline
\end{tabular}

Table 3. Organisational Focus Areas for Exploration

Hence, we hypothesise that organisational focus areas for exploration, as highlighted above, are positively associated with effective leadership for digital enterprises.

Additionally, we also theorise that strategic priorities are positively associated with organisational focus areas for exploration. The conflict between exploitation and exploration can be addressed by adopting a portfolio approach and setting strategic priorities. Companies should focus on activities to support cash generation in the short run as well as have action plans aimed at creating new products, services, and/or business models (Finzi, Firth, \& Lipton, 2018). Over a period, these activities may shift from an innovation focus to efficiency focus or vice versa, implying that the organisation's aim or direction remains balanced at any point of time.

Hence, we hypothesise that strategic priorities are positively associated with organisational focus areas for exploration for digital enterprises. 


\subsection{Digital Governance Practices for Exploitation}

The digital transformation process affects the entire organisation and resistance may be faced from different departments. A study (Matt, Hess, \& Benlian, 2015) states that in order to deal with resistance, leadership skills are essential and active involvement of the different stakeholders affected by the transformation is required. Resistance to change, poor communication amongst team members and lack of stakeholders' involvement or buy-in are some of the challenges faced by companies undergoing digital transformation (Solis, 2016). Increased connectivity and information sharing eliminate the hierarchical barriers and organisational boundaries which leads to transforming task-based activities into more projectbased activities, where employees participate in the creation of new value-added services (Cortellazzo et al., 2019). Hence, there is a compelling need for leaders to build proper governance practices to overcome such challenges. According to Tannou and Westerman (2012), governance is one of the key determinants of success in digital transformation.

Information Technology (IT) governance has been widely discussed as a supporting function to reap the benefits of IT in a business. Although the traditional IT governance has contributed to businesses in the past, it might not be able to reflect the realities of the current digital world. The current understanding of IT would involve the need to be aware of latest developments in in this digitised era. Firstly, products and services have become more digitalised, showing close integration of IT with business processes (Bharadwaj et al., 2013). Hence, resulting in cross-functional decision-making in contrast to traditional, autonomous functional-level decision-making. Secondly, the perception about IT is evolving as IT becomes more businessoriented involved in high-level strategic decision-making. Finally, with the advancement and speed of technological development, companies are motivated to develop and revise governance measures in order to cope and align with the accelerating IT-related decisionmaking processes. (Bongiorno et al., 2018). Therefore, the traditional view of IT governance will gradually be ineffective in today's digital enterprises. (Bongiorno et al., 2018).

Digital governance (IT Governance in digital enterprises) is a methodology that establishes accountability for digital policy, strategy, and standards. Digital Governance plays an important role in supporting organisational change, enables collaborative communications across organisational boundaries and a shared digital decision-making culture of an organisation. Governing this digital transformation requires leaders to determine the issues and challenges relating to the implementation of digital projects, and develop innovative and creative processes, stipulate new polices, roles and responsibilities (Bongiorno et al., 2018) to manage these projects effectively. There has been research conducted in the areas of leadership, processes, people, strategy, technology, and organisational dynamics, which influence the state of digital governance in the organisations (Dykes, 2012).

Effective digital governance processes help in digital development and clarify roles and responsibilities (Welchman, 2015). Study has also been done on IT risk management and resource management, which improves the effectiveness of digital governance processes (Lunardi, Maçada, \& Becker, 2014). As per the study by Devos and de Ginste (2015), the Digital Governance concept is rapidly evolving in the business world, especially over the last few years (Harvard Business Review, 2014). There are no best practices formally defined for digital governance. Each industry and business should develop their own digital governance model based on its maturity and market dynamics. Devos and de Ginste (2015) study has shown that those organisations which have established effective digital governance were able to generate 
higher returns to the extent of $40 \%$ on their IT investments as compared to their competitors without digital governance.

For this study, the digital governance practices for exploitation shown in Table 4 were important to achieve successful digital transformation.

\begin{tabular}{|c|c|c|}
\hline $\begin{array}{l}\text { Digital Governance } \\
\text { Practices for } \\
\text { Exploitation }\end{array}$ & Description & References \\
\hline $\begin{array}{l}\text { Regulatory } \\
\text { compliance }\end{array}$ & 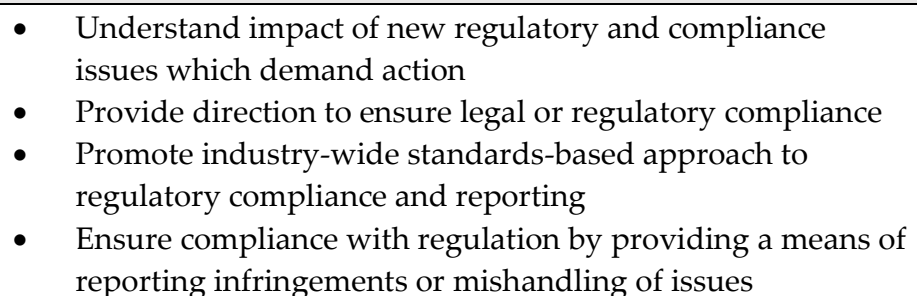 & $\begin{array}{l}\text { Butler \& O'Brien, } \\
2019 ; \\
\text { Bongiorno et al., } \\
2018\end{array}$ \\
\hline $\begin{array}{l}\text { Cyber security } \\
\text { planning }\end{array}$ & $\begin{array}{l}\text { - Senior management need to be aware of the growing } \\
\text { cybersecurity risks and plan and address these risks } \\
\text { accordingly } \\
\text { - Need to ensure security around organisational data assets } \\
\text { and personal privacy, protecting them all from theft or } \\
\text { external attacks. } \\
\text { - Establish a new balance between risk and opportunity } \\
\text { management }\end{array}$ & $\begin{array}{l}\text { Butler \& O’Brien, } \\
2019 ; \\
\text { Bongiorno et al., } \\
2018 ; \\
\text { Hyek \& Nendick, } \\
2014\end{array}$ \\
\hline Ethical data handling & $\begin{array}{l}\text { - } \quad \text { Recognize risks from unethical data practices and illegal use } \\
\text { of insights and mitigating these threats is critical for a } \\
\text { digital enterprise } \\
\text { - Proper management of personal data and compliance with } \\
\text { data protection laws } \\
\text { - Organisations that display themselves as untrustworthy data } \\
\text { custodians will face a major loss of brand equity. } \\
\text { Employees advised to customise their privacy settings and } \\
\text { respect other people's privacy, monitor and track their } \\
\text { digital footprint }\end{array}$ & $\begin{array}{l}\text { Bongiorno et al., } \\
\text { 2018; } \\
\text { Accenture, } 2016\end{array}$ \\
\hline $\begin{array}{l}\text { Social media } \\
\text { management }\end{array}$ & $\begin{array}{l}\text { - } \quad \text { Pay close attention to organisation's online reputation } \\
\text { - Determine how the Corporate brand is represented in social } \\
\text { media such as Facebook, Twitter, or YouTube or in } \\
\text { authenticated or unauthenticated web sites } \\
\text { - Aware of unauthorised data sharing by social media } \\
\text { platforms }\end{array}$ & $\begin{array}{l}\text { Steele, Allen, \& } \\
\text { Watkins, 2019; } \\
\text { Bongiorno et al., } \\
\text { 2018; } \\
\text { Tannou \& } \\
\text { Westerman, } 2012 \\
\end{array}$ \\
\hline $\begin{array}{l}\text { Employee } \\
\text { collaboration }\end{array}$ & $\begin{array}{l}\text { - Create space and opportunities for participation and } \\
\text { engaging employees in the change process } \\
\text { Expose employees to different ways of thinking and } \\
\text { engaging, cultivate employee collaboration and allow them } \\
\text { to embrace the digital culture }\end{array}$ & $\begin{array}{l}\text { Larjovuori et al., } \\
2018 ; \\
\text { Kane et al., 2017; } \\
\text { Tannou \& } \\
\text { Westerman, } 2012\end{array}$ \\
\hline
\end{tabular}

\section{Table 4. Digital Governance Practices for Exploitation}

Hence, we hypothesise that digital governance practices for exploitation, as highlighted above, are positively associated with effective leadership for digital enterprises. 


\section{Research Method, Data, and Analysis}

\subsection{Survey Instrument}

A quantitative approach was taken for the research with a strong empirical analysis to identify the antecedents of effective digital leadership in Asia Pacific. Through the identification of relevant measurements from a comprehensive literature review, a survey instrument was developed to test the research model and hypotheses in Figure 1. Content validity was ensured by adopting the scales for different measures from prior research (see Appendix). To facilitate measurement, the survey instrument utilised items on a five-point Likert scale rating ranging from strongly disagree, represented by 1, to strongly agree, represented by 5 . The survey instrument comprised a total of 35 questions and had three sections with the first section on demographics, followed by a section introducing the research topic and the third section related to the constructs.

\subsection{Sampling Process and Data collection}

The target population for the survey were business leaders from the Asia Pacific region. We have chosen to test our proposed model across Singapore, Sydney (Australia), Mumbai (India) and Dubai (UAE) where there is large concentration of business leaders who are familiar with the Asia Pacific region. Singapore is home to a large number of companies with Regional Headquarters (RHQ). For example, $46 \%$ of RHQ are based in Singapore across a diverse range of industries (Singapore Economic Development Board, 2020). Sydney has been the first choice for global companies within Australia, with over 600 multinational firms running their AsiaPacific operations from this city (NSW Treasury, 2019). India has been home to fastest-growing mature tech ecosystem. For example, Mumbai is the sixth fastest growing tech-hub in the world (London \& Partners, 2021). Dubai is the favoured city for the regional headquarters for the world's largest 500 companies (Rizvi, 2017).

The questionnaire framed was then pilot tested with a sample size of 10 participants for comprehensibility and the ability to express the research intention. A total of five domain experts were consulted to validate the model and questionnaire. Their inputs were integrated into the final model and questionnaire.

A series of Information Technology Management (ITM) Conclave events were organised in 2017 and 2018 targeting leaders and senior managers of enterprises focusing on the theme of digital transformation. These events were supported and promoted by Singapore Computer Society (SCS), Australian Computer Society (ACS), The National Association of Software and Service Companies (NASSCOM) and The Indus Entrepreneurs (TiE) across the cities Dubai, Mumbai, Singapore, and Sydney with a total participation of over 200 leaders and senior managers. We reached out to these participants through the initial mailing list of companies who have also indicated digital transformation as their top priority. The companies were selected based on their interest in participating, as well as their diversity. (Larjovuori et al., 2018). For this study, a random sample of business leaders and high-ranking managers involved in decision-making (such as CEOs, CIOs, senior managers, or project managers) who were familiar or involved in digital transformation in Asia Pacific were targeted. These companies spanned across different industries from the region that included IT, consulting, retail, banking and finance and healthcare. The participants were requested to participate in the survey through an online survey link. In the instructions given to the respondents, we asked them to respond to the questions by keeping their organisation in mind. A total of 120 
responses were received over a period of one month excluding the incomplete submissions. The demographic distribution of the sample is presented in Table 5 (120 respondents).

\begin{tabular}{|l|l|c|c|}
\hline $\begin{array}{l}\text { Demographic } \\
\text { Variable }\end{array}$ & Category & $\begin{array}{c}\text { Frequency } \\
\text { [N=120] }\end{array}$ & Percentage (\%) \\
\hline \multirow{4}{*}{ Size of firm } & Less than 50 & 22 & $18 \%$ \\
\cline { 2 - 4 } & 50 to 200 employees & 15 & $13 \%$ \\
\cline { 2 - 4 } & $\begin{array}{l}\text { More than } 200 \\
\text { employees }\end{array}$ & 83 & $69 \%$ \\
\hline \multirow{4}{*}{$\begin{array}{l}\text { Years associated } \\
\text { with ICT industry }\end{array}$} & $1-5$ years & 15 & $13 \%$ \\
\cline { 2 - 4 } & $5-10$ years & 37 & $31 \%$ \\
\cline { 2 - 4 } & 10 - 15 years & 29 & $24 \%$ \\
\cline { 2 - 4 } & More than 15 years & 39 & $32 \%$ \\
\hline \multirow{3}{*}{$\begin{array}{l}\text { Location of } \\
\text { organisation }\end{array}$} & Singapore & 53 & $44 \%$ \\
\cline { 2 - 4 } & India & 23 & $19 \%$ \\
\cline { 2 - 4 } & Australia & 15 & $13 \%$ \\
\cline { 2 - 4 } & UAE & 26 & $22 \%$ \\
\cline { 2 - 4 } & Others & 3 & $2 \%$ \\
\hline
\end{tabular}

Table 5. Demographic Profile of Survey Respondents ( $n=120)$

\subsection{Data Analysis}

Data analysis was conducted in two stages. In the first stage, the reliability and three types of validity examination; content validity, convergent validity, and discriminant validity, were conducted to assess the robustness of the measurement model. In the second stage, Partial Least Squares (PLS) path modelling was undertaken as it is preferred for research studies for its flexible modelling and identifying key drivers (Hair, Ringle, \& Sarstedt, 2011). The data analysis was carried out using ADANCO 2.0.1 to develop and evaluate the structural model and the causal relationships between the variables.

\subsubsection{Reliability}

The two variable reliability measurements used in this study are (1) Cronbach's alpha $(\alpha)$ and (2) Jöreskog's rho (@). A Cronbach's alpha coefficient which is greater than 0.6 and less than 1, is considered to be an acceptable level of reliability (Pallant, 2007; Hair, Black, Babin, \& Anderson, 2013). Jöreskog's rho evaluates composite reliability to appreciate the integrity and homogeneity of the model (Werts, 1978). As shown in Table 6, both Cronbach's alpha and composite reliability (Jöreskog's rho) exceeded their threshold values $(>0.70)$. This confirms the statistical significance of the model and demonstrates strong evidence of internal consistency reliability (Hair, Hult, Ringle, \& Sarstedt, 2016).

\subsubsection{Validity}

\section{Convergent Validity}

Carlson (2012) mentioned that convergent validity evaluates the degree of correspondence between two measures of variables; composite reliability (CR) and the average variance extracted (AVE). AVE refers to the ratio of the construct variance to the total variance among indicators (Hair et al. 2016; Roldán \& Sánchez-Franco, 2012). As shown in Table 6, the average variance extracted (AVE) value of each construct exceeded the threshold value of $>0.5$ (Fornell 
\& Larcker, 1981; Hair, Ringle, \& Sarstedt, 2011; Henseler, Hubona, \& Ray, 2016), thus indicating significant convergent validity (Hair et al., 2016). Hence, all constructs in the model have adequate reliability and convergent validity.

\begin{tabular}{|l|l|c|c|}
\hline \multicolumn{1}{|c|}{ Construct } & \multicolumn{1}{|c|}{$\begin{array}{c}\text { Average variance } \\
\text { extracted (AVE) }\end{array}$} & $\begin{array}{c}\text { Jöreskog's rho } \\
\left(\mathbf{p c}_{\mathbf{c}}\right.\end{array}$ & $\begin{array}{c}\text { Cronbach's alpha } \\
(\boldsymbol{\alpha})\end{array}$ \\
\hline Leadership Attributes & 0.5916 & 0.9096 & 0.8832 \\
\hline $\begin{array}{l}\text { Effective Digital Leadership } \\
\text { of Enterprises }\end{array}$ & 0.6149 & 0.9176 & 0.8948 \\
\hline $\begin{array}{l}\text { Digital Governance } \\
\text { Practices for Exploitation }\end{array}$ & 0.6076 & 0.8853 & 0.8376 \\
\hline Strategic Priorities & 0.5112 & 0.8023 & 0.6920 \\
\hline $\begin{array}{l}\text { Organisational Focus Areas } \\
\text { for Exploration }\end{array}$ & 0.6862 & 0.9291 & 0.9083 \\
\hline
\end{tabular}

Table 6. Convergent Validity and Reliability Statistics

\section{Discriminant Validity}

Discriminant validity ensures that the constructs that differ from each other are proven to be different (Henseler, Hubona, \& Ray, 2016). ADANCO 2.0.1 is used to test whether constructs are irrelevant or in truth random. As recommended by Fornell and Larcker (1981), the discriminant validity of the independent variables was examined by finding the square root of the AVE. The AVE measure of other variables should be lesser than the square root of AVE obtained from a particular variable. This Fornell-Larcker (1981) method is used for evaluating the degree of distinction between the variables. The measures of the square root of the AVE seen on the diagonal of Table 7 are all greater than the inter-construct correlations, thus confirming discriminant validity (Sarstedt, Wilczynski, \& Melewar, 2013). This demonstrates satisfactory convergent and discriminant validity.

\begin{tabular}{|l|l|l|l|l|l|}
\hline Construct & $\begin{array}{l}\text { Leadership } \\
\text { Attributes }\end{array}$ & $\begin{array}{l}\text { Effective Digital } \\
\text { Leadership of } \\
\text { Enterprises }\end{array}$ & $\begin{array}{l}\text { Digital } \\
\text { Governance } \\
\text { Practices for } \\
\text { Exploitation }\end{array}$ & $\begin{array}{l}\text { Strategic } \\
\text { Priorities }\end{array}$ & $\begin{array}{l}\text { Organisational } \\
\text { Focus Areas } \\
\text { for } \\
\text { Exploration }\end{array}$ \\
\hline $\begin{array}{l}\text { Leadership } \\
\text { Attributes }\end{array}$ & $\mathbf{0 . 5 9 1 6}$ & & & & \\
\hline $\begin{array}{l}\text { Effective } \\
\text { Digital } \\
\text { Leadership of } \\
\text { Enterprises }\end{array}$ & 0.3541 & $\mathbf{0 . 6 1 4 9}$ & & & \\
\hline $\begin{array}{l}\text { Digital } \\
\text { Governance } \\
\text { Practices for } \\
\text { Exploitation }\end{array}$ & 0.3762 & 0.3663 & $\mathbf{0 . 6 0 7 6}$ & $\mathbf{0 . 5 1 1 2}$ & \\
\hline $\begin{array}{l}\text { Strategic } \\
\text { Priorities }\end{array}$ & 0.3496 & 0.2551 & 0.2307 & & \\
\hline $\begin{array}{l}\text { Organisational } \\
\text { Focus Areas } \\
\text { for } \\
\text { Exploration }\end{array}$ & 0.1238 & & & 0.1045 & $\mathbf{0 . 6 8 6 2}$ \\
\hline
\end{tabular}

Table 7. Overall discriminant validity for each construct

Note: Squared correlations; AVE in the diagonal. 


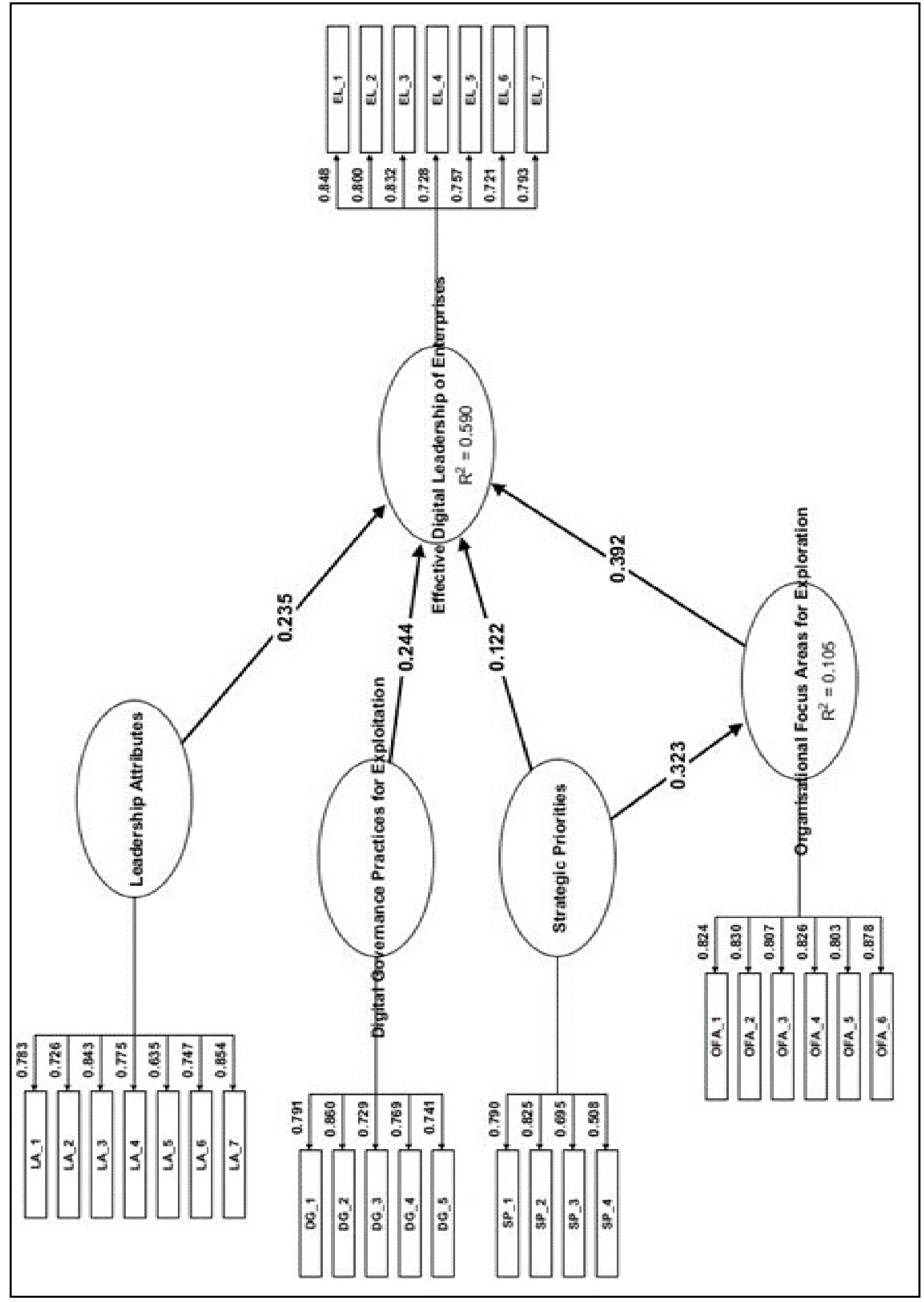

Figure 2. Structural equation model with path coefficients 


\subsection{Structured Equation Modelling / Path Analysis}

The structural equation model (SEM) shown in Figure 2 was developed to establish the relationship between the dependent and independent variables and examine their significance (Roldán \& Sánchez-Franco, 2012). Path modelling is a special case of structural equation modelling (SEM), in which single indicators are used in the model for each variable and the strength of each path is calculated as a product of the path coefficient along that path. The correlation is the equation of the sum of the contribution of all the paths through which the variables are connected. The strength of each path is calculated as a product of the path coefficient along that path. In our research, the results of the analysis in Figure 2 shows that with its R2 value being 0.590 , the model was acceptable, and all 5 hypotheses were supported (Hooper, Coughlan, \& Mullen, 2008).

\subsubsection{Hypothesis Testing}

In our research, five hypotheses were postulated. The structural model and hypothesised relationships were tested using a standardised path coefficient $(\beta)$ and t-statistics (Table 8 ) at $\mathrm{p}<0.01$. The threshold critical t-values ( $\alpha$; two-sided test) at a significance level of $\alpha=0.01, \alpha$ $=0.05$ and $\alpha=0.10$ were 2.57, 1.96 and 1.65, respectively (Hair et al., 2016).

The structural model revealed that 3 hypotheses were supported by the relationships at the $p$ $<0.01$ significance level while 2 hypotheses was supported by the relationships at the $\mathrm{p}<0.05$ significance level. The results (Table 8) authenticate that all five proposed latent constructs had significant effects on effective digital leadership of enterprises.

Our findings show that the relationships between leadership attributes and effective digital leadership of enterprises $(\beta=0.2353, t=2.6242, p<0.01)$, organisational focus areas for exploration and effective digital leadership of enterprises $(\beta=0.3922, t=3.3078, p<0.01)$, and digital governance practices for exploitation and on effective digital leadership of enterprises $(\beta=0.22442, t=2.6646, p<0.01)$, were statistically significant confirming the support for $\mathrm{H} 1$, H3 and H5 (Table 8).

The structural model further revealed that two other hypotheses were supported at the $\mathrm{p}<$ 0.05 significance level (see Figure 2). The relationship between strategic priorities and effective digital leadership of enterprises $(\beta=0.2486, t=2.5745, \mathrm{p}<0.05)$ and strategic priorities and organisational focus areas for exploration $(\beta=0.3233, \mathrm{t}=2.3553, \mathrm{p}<0.05)$ were statistically significant, confirming support for $\mathrm{H} 2$ and $\mathrm{H} 4$ (Table 8).

\section{Discussion}

The results of the analysis have shown that leadership attributes, strategic priorities, organisational focus areas for exploration and digital governance practices for exploitation, are significant antecedents of effective digital leadership, thus supporting the hypotheses, $\mathrm{H} 1$, $\mathrm{H} 2, \mathrm{H} 3, \mathrm{H} 4$ and $\mathrm{H} 5$. 


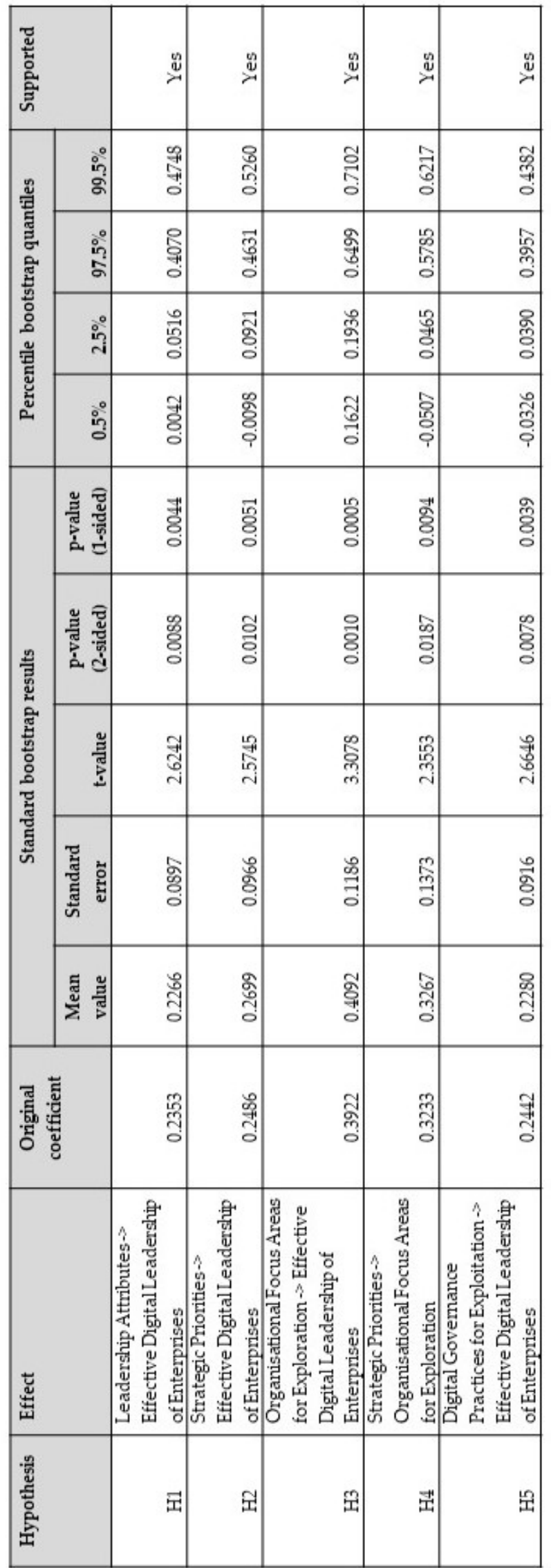

Table 8. Outcomes of the hypothesis testing

Note: ${ }^{*} p<0.10 ;{ }^{* *} p<0.05 ;{ }^{* *} p<0.01$ (two-sided) confidence intervals for significance testing. 


\subsection{Summary of Findings}

The findings from this study have highlighted that leadership attributes have a positive impact on effective digital leadership for digital enterprises. Various past studies examining the leadership traits and qualities suggests that state that digital leaders should be able pursue a clear and meaningful digital vision, inspire the employees, and have the capability to execute strategies to actualize the digitalisation process of the enterprise (Swift \& Lange, 2018; Larjovuori et al., 2018). Leadership competencies that organisations need to develop in their leaders include digital vision, digital knowledge, empowerment, and managing diverse teams (Imran et al., 2020). Leaders would also be open to new possibilities, new markets, new customers, and new innovations by taking risks (Larjovuori et al., 2018). This is consistent with studies on ambidextrous leadership which state that leaders embrace ambiguity, ambivalence, uncertainty, tension, and conflict (Finzi, Firth, \& Lipton, 2018). Other studies state that a leader needs to be agile, adaptable to changes, open-minded (Hill, 2020; Kane et al., 2019; Cortellazzo et al., 2019), drive and cultivate innovation (Dubey, 2019; Swift \& Lange, 2018) in a fluid and evolving market. Another study mentioned the need for leaders to collaborate and build partnerships with key stakeholders for new digital business opportunities (Larjovuori et al., 2018). In order to support the digital vision of the leader, leaders are to source, retain, train, and motivate employees to drive and deliver the digital strategy of the organisation (Finzi, Firth, \& Lipton, 2018).

Strategic priorities have a moderate impact on effective digital leadership for enterprises. Based on previous studies, leaders are expected to seek high-level priorities for the organisation and create new business models and adapt to changing business trends (Tardieu et al., 2020; Popadiuk et al., 2018). In order to sustain and compete in the dynamic competitive environment, leaders will have to re-evaluate strategies, competitive strengths and review assets that give potential competitive advantage (Tardieu et al., 2020; Hyek \& Nendick, 2014). In addition, leaders must make thoughtful decisions about leveraging technologies to innovate the business (Donahue, 2020; Popadiuk et al., 2018). Other studies state that leaders have to administer cost control measures and generate savings which can in turn be invested to drive growth, create new opportunities, and become more competitive in the global environment (Ittner, 2019; Gottlieb, \& Willmott, 2014).

Organisational focus areas for exploration have higher impact on effective digital leadership for digital enterprises. This is consistent with previous similar studies which stated that to compete in a fast-changing digital environment, an effective digital leader will need to focus on diversifying the organisation's business model through building strategic partnerships (Della Corte et al., 2019; Fenwick \& Schadler, 2018). Another study mentioned that it was necessary for a business enterprise to create a data-driven culture by capitalising on data sharing and analytics (Davenport \& Mittal, 2020; Jimenez et al., 2018; Geissbauer, Vedso, \& Schrauf, 2016), adopt disruptive technologies to become better integrated with business value chain partners and improve efficiency (Finzi, Firth, \& Lipton, 2018; De la Boutetière, Montagner, \& Reich, 2018) and ensure end-to-end digitisation of all essential functions and integrate into digital ecosystems with value chain partners (Chee \& Young, 2020; Geissbauer, Vedso, \& Schrauf, 2016). Studies also stated that to accelerate digital transformation, digital leaders will need to set up cross-functional teams to foster digital innovation (Kane et al., 2019; Link, 2018) and empower employees to share new ideas and initiatives where digitisation or digital technologies can be adopted in the business enterprise (Kane et al., 2019; De la Boutetière et al., 2018). 
It was observed that strategic priorities and organisational focus areas for exploration indicated a significant relationship. This is in line with the related findings (Wrede, Velamuri, \& Dauth, 2020) that states that strategic prioritisation influences the focus areas for exploration as the overall corporate strategy has integrated digitalisation and there is clear communication on the goals of digitalisation.

Past studies examining digital governance practices state the need for leaders to not only understand the impact of new regulatory and compliance but also to promote industry-wide standards-based approach to regulatory compliance and reporting (Butler \& O'Brien, 2019). Another study stated the need for leaders to be aware of the growing cybersecurity risks and unethical data practices and to enforce security controls to ensure privacy and compliance with data protection laws and practices (Butler \& O'Brien, 2019; Bongiorno et al., 2018, Accenture, 2016). Furthermore, with the widespread use of social media, leaders have to constantly pay attention to the organisation's online reputation (Steele, Allen, \& Watkins, 2019). In order for employees to embrace the digital culture, leaders have to engage and create opportunities for employees to participate in the digitalisation change process (Larjovuori et al., 2018; Kane et al., 2017).

\subsection{Benefits of Effective Leadership}

The benefits of effective digital leadership include the capacity to sense, shape and seize digital opportunities, and maintain competitiveness through enhancing, combining, protecting, and, reconfiguring the business enterprise's assets (Teece, 2007; Carcary, Doherty, \& Conway, 2016).

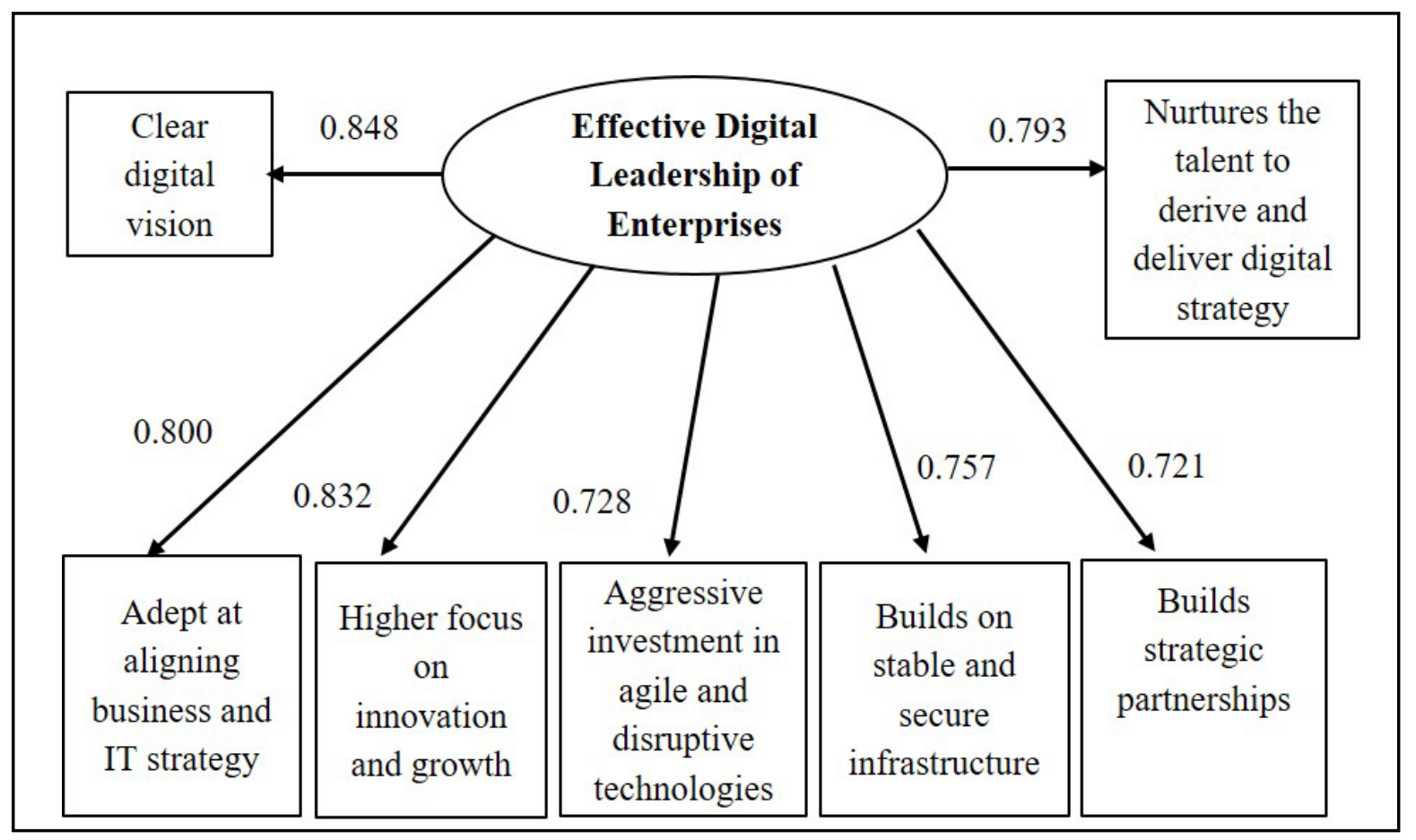

Figure 3. Effective Digital Leadership path coefficients

In the above structural equation model, Figure 3, the path coefficient for clear digital vision is 0.848 , adept at aligning business and IT strategy is 0.800 , higher focus on innovation and growth is 0.832 and nurture the talent to derive and deliver digital strategy is 0.793 . Whereas the path coefficient for aggressive investment in agile and disruptive technologies is 0.728 , 
build on stable and secure infrastructure is 0.757 , and build strategic partnerships is 0.721 . This implies that clear digital vision, higher focus on innovation and growth and adept at aligning business and IT strategy (Heneghan, Snyder, \& Symons, 2017), have the strongest impact on effective leadership, along with nurture the talent to derive and deliver digital strategy (Tong, 2017) with a path coefficient of approximately 0.8. Aggressive investment in agile and disruptive technologies, build on stable and secure infrastructure and build strategic partnerships have a moderate effect on effective leadership.

Leadership plays an important role in digital transformation. (Zhang et al., 2011) study states that transformational leadership enhances team coordination, and this results in high team performance. Transformational leadership improves the spirits, motivation, and performance of their followers. These include connecting the follower's sense of identity to the mission; inspire them; challenging followers to take greater responsibility and understanding their strengths and weaknesses to be able to assign the responsibilities accordingly. (García-Morales et al., 2012) study suggests that transformational leadership, through organisational learning and innovation, is needed to improve an organisation's performance in the current changing business environment. Chen et al., 2012) further states that transformational leadership plays an important role in fostering innovation and is effective at the strategic business unit (SBU) level.

From the survey findings, it shows that the transformational leadership style is more suited to be adopted by digital leaders of enterprises as the factors such as having a digital vision, foster innovation, agility, natural collaborator, building digital talent, are in accordance with the theory of transformational leadership (Bass \& Riggio, 2006). Holistically, the results highlight the importance of the factors considered and validate the implications of effective leadership for digital transformation. Therefore, these factors must be taken into consideration by the business leaders of organisations who have embarked on the digital transformation journey to stay competitive in the digital economy. However, future research incorporating additional factors can be conducted to improve the accuracy and dynamism of the proposed model.

\section{Implications}

Despite the positive attitude towards digital transformation and its benefits, there has not been much study linking leadership practices and effective digital leadership of enterprises (Li et al., 2016). Successful digital transformation starts from the top management and digital transformation is inherently cross-functional and will require new leadership practices to engage with and transform the organisation (Yokoi, Shan, Wade, \& Macaulay, 2019).

\subsection{Implications for Research}

Firstly, this study has quantitatively affirmed the positive relation between leadership attributes, strategic priorities, organisational focus areas for exploration and digital governance practices for exploitation, and the effective leadership of enterprises in Asia Pacific. Secondly, as research linking leadership and digital transformation is sparse, this paper will set a foundation for future studies related to effective digital leadership.

Thirdly, this is one of the initial studies to explore leadership practices based on theoretical lens of transformation leadership, ambidexterity, and dynamic capabilities. The authors extended the literature on various variables by proposing a conceptual model that sets a theoretical foundation to understand the antecedents of effective leadership. An in-depth 
study to examine these variables can be carried out for future research. The model in this study (Figure 2) can be used as a guide for future research involving the understanding of antecedents of effective leadership of enterprises. Lastly, the results of the study can be further validated with other regions by examining the leadership attributes, strategic priorities, organisational and digital governance practices.

\subsection{Implications for Practice}

This study has many important implications and recommendations for leaders, organisations, training institutes and government involved in digital transformation across Asia Pacific. Firstly, given that only $7 \%$ of enterprises in Asia Pacific are identified as digital leaders (Jimenez et al., 2018), there is a need for increased awareness of key leadership practices for effective digital leadership. The key factors identified such as leadership attributes, strategic priorities, organisational focus areas for exploration and digital governance practices for exploitation, will help enterprises to strategize and focus on the key factors to accelerate digital transformation and achieve effective digital leadership. There is a need to balance exploration and exploitation and put digital governance practices in place. The significant relationship of digital governance practices for exploitation indicates that senior management should work closely with the senior leaders and the business heads to develop digital business strategies that facilitate the strategic and secure use of technology across the enterprises to produce the desired business outcomes (Heneghan, Snyder, \& Symons, 2017). There is a need to ensure that businesses build their digital capabilities on top of a stable and secure infrastructure whether internally or externally sourced and are effective at selecting the most appropriate technologies and architectures (Heneghan, Snyder, \& Symons, 2017).

Secondly, with the increased focus on digital transformation, there is opportunity for leaders across Asia Pacific to develop and nurture the right leadership attributes and promote ambidextrous leadership. The digital leadership has to be constantly developed with top managers' ambidexterity (Della Corte et al., 2019). The digital age requires rethinking the traditional leadership and command-and-control base governance that has been prevalent for so long in Asia Pacific. Key attributes identified such as risk-taking, agility, tolerance of ambiguity, are critical for leaders for Asia Pacific to develop digital enterprises. It is important for them to accurately sense changes in their competitive environment, including potential shifts in technology, competition, customers and set strategic priorities and identify areas for exploration for the organisation. Hence, leaders will need to seize opportunities in a timely manner by successfully innovating and implementing new systems in a changing business environment (Popadiuk, Luz, \& Kretschmer, 2018) and make significant investments in new technologies to achieve the full value and enterprise-wide, game-changing innovation (Ghosh, Burden, \& Wilson, 2019).

Thirdly, to successfully transition to the new digital economy, organisations need to find, recruit, and retain leaders and senior managers with digital skillsets and training institutes could play a critical role here. For example, business schools should accelerate collaborations with industry to develop and align the right curriculum and undertake more internships and digital transformation projects giving opportunity for students to enhance their leadership attributes and learn new practices for ambidextrous leadership.

Lastly, digital technologies offer opportunities for higher productivity growth and improvements in living standards. Past studies indicate that of government incentives and regulatory support across Asia Pacific vary widely (Kumar, 2017). Consequently, there is a 
need for governments across Asia Pacific to promote and incentivise leadership practices for effective digital leadership and accelerate organisational capability development in the areas of digital innovation and catalyse collaborations. There is a need for governments to put in place and update regulations in the areas of cybersecurity and policies and promote digital governance practices especially across small and medium-sized enterprises.

\section{Limitations of the Study and Future Scope}

Although this study makes contributions in terms of better understanding of the factors influencing effective leadership for digital enterprises, there are a few limitations. Firstly, this research mainly focused on collecting data within the Asia Pacific region represented by data of sample size 120 from four main cities namely Dubai, Mumbai, Sydney, and Singapore. The observation and inferences were derived from a targeted survey of the Asia Pacific region. Therefore, generalizing the results can be viewed as an issue. The research highlights the significant factors that influence effective leadership for digital transformation, but more research is required on this subject to uncover further dimensions. Future research can include data collection from other regions such as America, Europe and Africa which also may have different economic, governance and infrastructural developments. Secondly, even though we have identified a few variables that influence effective leadership for digital transformation, upcoming revisions may discover additional factors to enhance the model further. Thirdly, the research model framed is cross-sectional in nature which means, with this research model, we have measured the perceptions at a single point of time. However, there is a likelihood of changes expected in the leadership style in future as organisations transform to adapt to industry and technological advancement.

\section{Conclusion}

This study aimed at identifying the antecedents of effective digital leadership of enterprises in Asia Pacific. The literature review conducted identified leadership attributes and practices that would be of great influence on digital leadership of enterprises. The proposed research model included five hypotheses and the results of the structural equation model analysis provide insights to the leaders and enterprises of Asia Pacific to help rethink the traditional leadership and governance practices. Key attributes identified such as risk taking, agility, tolerance of ambiguity, are critical for leaders in Asia Pacific to develop digital enterprises. The conceptualisation of factors influencing effective leadership provides direction to organisations, technology professionals, business leaders and researchers to focus not only on leadership traits or qualities but also on other factors such as strategic priorities, organisational focus areas and digital governance practices. Our study will help the enterprises to drive digital transformation projects and collaborate with the service providers to increase the success rate of digital transformation and create more digital leaders in Asia Pacific.

\section{Acknowledgements}

The authors would like to thank the Editor and the two anonymous reviewers of this journal for their constructive feedback and suggestions for improvement of this paper.

\section{References}

Accenture. (2016). The Ethics of Data Sharing: A guide to best practices and governance [White paper]. Accenture. Retrieved form https://www.accenture.com/_acnmedia/pdf35/accenture-the-ethics-of-data-sharing.pdf. 
Agarwal, R., \& Helfat, C. E. (2009). Strategic renewal of organizations. Organization Science, 20(2), 281-293. https://doi.org/10.1287/orsc.1090.0423

Bahl, M. (2016). The work ahead - The Future of Businesses and Jobs in Asia Pacific's Digital Economy [White paper]. Cognizant. Retrieved form https://www.cognizant.com/whitepapers/thework-ahead-the-future-of-business-and-jobs-in-asia-pacifics-digital-economycodex2255.pdf

Baškarada, S., Watson, J., \& Cromarty, J. (2016). Leadership and organizational ambidexterity. Journal of Management Development, 35(6), pp. 778-788.

https://doi.org/10.1108/JMD-01-2016-0004

Bass, B. M. (1985). Leadership and performance beyond expectations. Collier Macmillan. London, UK.

Bass, B. M. (1990). Bass \& Stogdill's Handbook of Leadership: Theory, Research and Managerial Applications. New York: The Free Press.

Bass, B. M. (1999). Two decades of research and development in transformational leadership. European Journal of Work and Organizational Psychology, 8(1), 9-32. https://doi.org/10.1080/135943299398410

Bass, B.M., \& Riggio, R.E., (2006). Transformational leadership, 2nd ed. L. Erlbaum Associates, Mahwah, N.J. https://doi.org/10.1080/10887150701451312

Bharadwaj, A., El Sawy, O. A., Pavlou, P. A., \& Venkatraman, N. (2013). Digital business strategy: toward a next generation of insights. MIS Quarterly, 471-482.

Bongiorno, G., Rizzo, D., \& Vaia, G. (2018). CIOs and the digital transformation: a new leadership role. In CIOs and the Digital Transformation (pp. 1-9). Springer, Cham. https://DOI 10.1007/978-3-319-31026-8_1

Burns, J. M. (1978). Row. New York.

Burley, K. (2019, December 2). Emergence of Traditional Leadership Styles. Retrieved from https://bizfluent.com/info-8469011-emergence-traditional-leadership-styles.html.

Butler, T., \& O'Brien, L. (2019). Understanding RegTech for digital regulatory compliance. In Disrupting Finance (pp. 85-102). Palgrave Pivot, Cham. https://doi.org/10.1007/978-3030-02330-0_6

Carcary, M., Doherty, E., \& Conway, G. (2016, September). A dynamic capability approach to digital transformation: a focus on key foundational themes. In The European Conference on Information Systems Management (p. 20). Academic Conferences International Limited.

Carlson, K. D., \& Herdman, A. O. (2012). Understanding the impact of convergent validity on research results. Organizational Research Methods, 15, 17-32. https://doi.org/10.1177/1094428110392383.

Cascio, W. F., \& Montealegre, R. (2016). How technology is changing work and organizations. Annual Review of Organizational Psychology and Organizational Behavior, 3, 349-375. https://doi.org/10.1146/annurev-orgpsych-041015-062352

Chee, C. W., \& Young, H. K. (2020). Procurement: making digital transformation work for you. Retrieved from https://www.de.kearney.com/procurement/article?/a/procurementriding-the-transformative-digital-wave.

Chen, M. Y. C., Lin, C. Y. Y., Lin, H. E., \& McDonough, E. F. (2012). Does transformational leadership facilitate technological innovation? The moderating roles of innovative culture and incentive compensation. Asia Pacific Journal of Management, 29(2), 239-264. https://doi.org/10.1007/s10490-012-9285-9

CISCO. (2020). CISCO Annual Internet Report (2018 - 2023). [White paper]. CISCO. Retrieved from https://www.cisco.com/c/en/us/solutions/collateral/executive-perspectives/ 
annual-internet-report/white-paper-c11-741490.html.

Cortellazzo, L., Bruni, E., \& Zampieri, R. (2019). The role of leadership in a digitalized world: a review. Frontiers in Psychology, 10, 1938. https://doi.org/10.3389/fpsyg.2019.01938

Cullen, D., Hui, D., \& Kittle, G. (2019). Transforming Asia: The search for digital leaders. Heidrick \& Struggles. Retrieved from https://www.heidrick.com/KnowledgeCenter/Publication/Transforming_Asia_The_search_for_digital_leaders.

Dahlström, P., Desmet, D., \& Singer, M. (2017). The seven decisions that matter in a digital transformation: A CEO's guide to reinvention. Digital McKinsey article (Feb 2017).

Davenport, T., \& Mittal, N. (2020). How CEOs Can Lead a Data-Driven Culture. Harvard Business Review. Retrieved from https://hbr.org/2020/03/how-ceos-can-lead-a-datadriven-culture.

De la Boutetière, H., Montagner, A., \& Reich, A. (2018). Unlocking Success in Digital Transformations. McKinsey \& Company. Retrieved from https://www.mckinsey.com/ /media/McKinsey/Business\%20Functions/Organization/O ur\%20Insights/Unlocking\%20success\%20in\%20digital\%20transformations/Unlockingsuccess-in-digital-transformations.ashx.

Della Corte, V., Del Gaudio, G., \& Sepe, F. (2019). Leadership in the Digital Realm: What Are the Main Challenges?. In Digital Leadership-A New Leadership Style for the 21st Century. IntechOpen. https://doi.org/10.5772/intechopen.89856

Deloitte (2016). Decoding Digital Leadership. Deloitte. Retrieved from https://www2.deloitte.com/content/dam/Deloitte/uk/Documents/public-sector/deloitteuk-decoding-digital-leadership.pdf.

Deloitte (2017). How do companies prepare for the opportunities and challenges for digitalisation? Retrieved from https://www2.deloitte.com/content/dam/Deloitte/ch/ Documents/consumer-business/ch-cip-en-swiss-transformation.pdf.

Devos, J., \& Van de Ginste, K. (2015). Towards a theoretical foundation of IT governance: the COBIT 5 case. In ECIME, 18 (2), pp. 95-103). Academic Publishing Limited.

Diaz-Saenz, H. R. (2011). Transformational leadership. The SAGE handbook of leadership, 5(1), 299-310.

Donahue, C. (2020). How To Keep Pace with Digital Transformation and Avoid Becoming Obsolete. Retrieved from https://www.forbes.com/sites/theyec/2020/02/12/how-to-keeppace-with-digital-transformation-and-avoid-becoming-obsolete/\#21b0d7984861.

Dubey, A. (2019). This is what great leadership looks like in the digital age. [online] World Economic Forum. Retrieved from https://www.weforum.org/agenda/2019/04/ leadership-digital-age-leader/.

Dykes, B. (2012). How to create a data-driven dynasty. Adobe. Retrieved from https://smartcomm.net.au/wp-content/uploads/2016/11/how-to-create-a-data-drivendynasty.pdf.

El Sawy, O. A., Kræmmergaard, P., Amsinck, H., \& Vinther, A. L. (2020). How LEGO Built the Foundations and Enterprise Capabilities for Digital Leadership. Strategic Information Management, 174-201. https://doi.org/10.4324/9780429286797-8

Fatima, T., Majeed, M., \& Saeed, I. (2017). Does Participative Leadership Promote Innovative Work Behavior: The Moderated Mediation Model. Business \& Economic Review, 9(4), 139156. https://doi.org/10.22547/ber/9.4.7

Fenwick, N., \& Schadler, T. (2018). Digital Rewrites the Rules of Business. Forrester, Cambridge, Massachusettes. 
Finzi, B., Firth, V., \& Lipton, M. (2018). Ambidextrous leadership: Keystone of the undisruptable CEO. Deloitte Insights.

Fornell, C., \& Larcker, D. F. (1981). Structural Equation Models with Unobservable Variables and Measurement Error: Algebra and Statistics. Journal of Marketing Research, 18(3), 382388. https://doi.org/10.2307/3150980

García-Morales, V. J., Jiménez-Barrionuevo, M. M., \& Gutiérrez-Gutiérrez, L. (2012). Transformational leadership influence on organizational performance through organizational learning and innovation. Journal of Business Research, 65(7), 1040-1050. https://doi.org/10.1016/j.jbusres.2011.03.005

Geissbauer, R., Vedso, J., \& Schrauf, S. (2016). Industry 4.0: Building the Digital Enterprise. PwC. Retrieved from https://www.pwc.com/gx/en/industries/industries-4.0/landingpage/industry-4.0-building-your-digital-enterprise-april-2016.pdf.

Gentle, C. \& Metselaar, J. (2020). Achieving Ambidextrous Leadership: Driving 'Perform \& Transform' Innovation for Step-Changed Business Results. Retrieved from https://cmr.berkeley.edu/2020/04/ambidextrous-leadership/.

Ghosh, B., Burden, A., \& Wilson, J. (2019). How to scale innovation and achieve full value with Future Systems. Accenture. Retrieved from https://www.accenture.com/_acnmedia/ thought-leadership-assets/pdf/accenture-future-systems-report.pdf.

Gottlieb, J., \& Willmott, P. (2014). The digital tipping point: McKinsey global survey results. McKinsey \& Company, McKinsey Quarterly.

Hair, J. F., Ringle, C. M., \& Sarstedt, M. (2011). PLS-SEM: Indeed a silver bullet. Journal of Marketing Theory and Practice, 19(2), 139-152. https://doi.org/10.2753/mtp10696679190202

Hair, J. F., Black, W. C., Babin, B. J., \& Anderson, R. E. (2013). Multivariate data analysis. Pearson New International Edition. Pearson Higher Ed.

Hair Jr, J. F., Hult, G. T. M., Ringle, C., \& Sarstedt, M. (2016). A primer on partial least squares structural equation modeling (PLS-SEM). Sage publications, USA.

Harvard Business Review (2014). Delivering on the promise of Digital Transformation. Harvard Business Review Analytic Services Report 2014. Retrieved from https://www.bmcsoftware.sg/content/dam/bmc/migration/pdf/HBR_BMC_Report_Au g2014-Final.pdf.

Harvard Business Review (2017). Operationalizing Digital Transformation: New Insights into Making Digital Work. Harvard Business Review Analytic Services Report 2017. Harvard Business School Publishing. Retrieved from https://hbr.org/resources/pdfs/comm/xl/ HBRASOperationalizingDigitalTransformation.pdf.

Havermans, L. A., Den Hartog, D. N., Keegan, A., \& Uhl-Bien, M. (2015). Exploring the role of leadership in enabling contextual ambidexterity. Human Resource Management, 54(1), 179-200. https://doi.org/10.1002/hrm.21764

Heneghan, L., Snyder, M., \& Symons, C. (2017). The route to digital business leadership. KPMG. Retrieved from https://assets.kpmg/content/dam/kpmg/xx/pdf/2017/09/theroute-to-digital-business-leadership.pdf.

Henseler, J., Hubona, G., \& Ray, P. A. (2016). Using PLS path modeling in new technology research: updated guidelines. Industrial Management $\mathcal{E}$ Data Systems. https://doi.org/10.1108/IMDS-09-2015-0382

Hess, T., Matt, C., Benlian, A., \& Wiesböck, F. (2020). Options for formulating a digital transformation strategy. In Strategic Information Management (pp. 151-173). Routledge. https://doi.org/10.4324/9780429286797-7 
Hill, L. A. (2020). Being the Agile Boss. MIT Sloan Management Review, 62(1), 7-10.

Hooper, D., Coughlan, J., \& Mullen, M. R. (2008). Structural equation modelling: Guidelines for determining model fit. Electronic Journal of Business Research Methods, 6(1), 53-60.

Huawei. (2020, August 6). Huawei Empowers Asia Pacific Digital Transformation, Leading to Adaptive Enterprises in Post-COVID World. Retrieved from https://e.huawei.com/sg/news/ebg/2020/asia-pacific-digital-transformation.

Hyek, P., \& Nendick, J. (2014). Sustaining digital leadership. Ernst and Young.

International Data Corporation (IDC). (2020, November 4). IDC Predicts 65\% of APAC* GDP will be Digitalized Reaching US\$1.2 Trillion in Spending by 2022. Retrieved from https://www.idc.com/getdoc.jsp?containerId=prAP46972820.

International Data Group (IDG). (2018). 2018 State of Digital Business Transformation [White paper]. IDG. https://www.idg.com/tools-for-marketers/2018-state-of-digital-businesstransformation-white-paper/.

Imran, F., Shahzad, K., Butt, A., \& Kantola, J. (2020, July). Leadership Competencies for Digital Transformation: Evidence from Multiple Cases. In International Conference on Applied Human Factors and Ergonomics (pp. 81-87). Springer, Cham.4. http://dx.doi.org/0.1007/978-3-030-50791-6_11

Ittner, C. (2019). How Digital Technology Is Transforming Cost Management. Retrieved from https://knowledge.wharton.upenn.edu/article/cost-management-in-the-digital-age/.

Jimenez, D. Z., Lim, V., Cheok, L., \& Ng, H. (2018). Unlocking the economic impact of digital transformation in Asia Pacific [White paper]. Microsoft and International Data Corporation (IDC) Asia/Pacific. https://news.microsoft.com/wpcontent/uploads/prod/sites/43/2018/11/Unlocking-the-economic-impact-of-digitaltransformation.pdf.

Judge, T. A., Bono, J. E., Ilies, R., \& Gerhardt, M. W. (2002). Personality and leadership: a qualitative and quantitative review. Journal of Applied Psychology, 87(4), 765-780. https://doi.org/10.1037/0021-9010.87.4.765

Kahai, S. S. (2013). Leading in a digital age: What's different, issues raised, and what we know. Exploring Distance in Leader-Follower Relationships: When Near is Far and Far is Near. New York, Routledge, S, 63-108.

Kane, G. C., Palmer, D., Phillips, A. N., Kiron, D., \& Buckley, N. (2015). Strategy, not technology, drives digital transformation. MIT Sloan Management Review and Deloitte University Press, 14(1-25).

Kane, G. C., Palmer, D., Nguyen-Phillips, A., Kiron, D., \& Buckley, N. (2017). Achieving digital maturity. MIT Sloan Management Review, 59(1).

Kane, G. C., Phillips, A. N., Copulsky, J., \& Andrus, G. (2019). How Digital Leadership Is (n't) Different. MIT Sloan Management Review, 60(3), 34-39.

Karimi, J., \& Walter, Z. (2015). The role of dynamic capabilities in responding to digital disruption: A factor-based study of the newspaper industry. Journal of Management Information Systems, 32(1), 39-81. https://doi.org/10.1080/07421222.2015.1029380

Knight, W. (2020). The 9 dimensions of innovation for digital leaders. Retrieved from https://digileaders.com/the-9-dimensions-of-innovation-for-digital-leaders.

Kohli, R., \& Johnson, S. (2011). Digital Transformation in Latecomer Industries: CIO and CEO Leadership Lessons from Encana Oil \& Gas (USA) Inc. MIS Quarterly Executive, 10(4).

Kassotaki, O. (2019). Ambidextrous leadership in high technology organizations. Organizational Dynamics, 48(2), 37-43. https://doi.org/10.1016/j.orgdyn.2018.10.001 
Kreutzer, R. T., Neugebauer, T., \& Pattloch, A. (2018). Digital Business Leadership: Digital Transformation, Business Model Innovation, Agile Organization, Change Management (pp. 263). Springer, Berlin.

Kumar, K. N. (2017). Digital Transformation in Asia-Pacific. Cutter Consortium. Retrieved from https://www.cutter.com/article/digital-transformation-asia-pacific-2017-495011.

Larjovuori, R. L., Bordi, L., Mäkiniemi, J. P., \& Heikkilä-Tammi, K. (2016). The role of leadership and employee well-being in organizational digitalization. Tiziana RussoSpenaand Cristina Mele, 1159.

Larjovuori, R. L., Bordi, L., \& Heikkilä-Tammi, K. (2018, October). Leadership in the digital business transformation. In Proceedings of the 22nd International Academic Mindtrek Conference (pp. 212-221). https://doi.org/10.1145/3275116.3275122

Li, W., Liu, K., Belitski, M., Ghobadian, A., \& O'Regan, N. (2016). e-Leadership through strategic alignment: An empirical study of small-and medium-sized enterprises in the digital age. Journal of Information Technology, 31(2), 185-206. https://doi.org/10.1057/jit.2016.10

Link, J. (2018). Why Organisations Need Digital Leaders with these Five Key Strengths. Forbes Media LLC. Retrieved from https://www.forbes.com/sites/Forbeshumanresources council/2018/10/04/why-organizations-need-digital-leaders-with-these-five-keystrengths/\#12b873567aee.

Liu, L., Yu, B., \& Wu, W. (2019). The Formation and Effects of Exploitative Dynamic Capabilities and Explorative Dynamic Capabilities: An Empirical Study. Sustainability, 11(9), 2581. https://doi.org/10.3390/su11092581

London \& Partners. (2021, January 14). Global Tech Investors Show Confidence in London. Retrieved from https://media.londonandpartners.com/news/global-tech-investorsshow-confidence-in-london.

Lunardi, G. L., Maçada, A. C. G., \& Becker, J. L. (2014, January). IT governance effectiveness and its antecedents: An empirical examination in Brazilian firms. In 2014 47th Hawaii International Conference on System Sciences (pp. 4376-4385). IEEE. https://doi.org/10.1109/hicss.2014.540

March, J. G. (1991). Exploration and exploitation in organizational learning. Organization Science, 2(1), 71-87.

Matt, C., Hess, T., \& Benlian, A. (2015). Digital transformation strategies. Business $\mathcal{E}$ Information Systems Engineering, 57(5), 339-343. https://doi.org/10.1007/s12599-015-0401-5

Neubauer, R., Tarling, A., \& Wade, M. (2017). Redefining leadership for a digital age. Global Centre for Digital Business Transformation, 1-15.

NSW Treasury. (2019). Sydney Facts. Retrieved from https://invest.nsw.gov.au/whynsw/sydney-facts.

O Reilly, C. A., \& Tushman, M. L. (2004). The ambidextrous organization. Harvard Business Review, 82(4), 74-83.

O'Reilly III, C. A., \& Tushman, M. L. (2008). Ambidexterity as a dynamic capability: Resolving the innovator's dilemma. Research in Organizational Behavior, 28, 185-206. https://doi.org/10.1016/j.riob.2008.06.002

O'Reilly III, C. A., \& Tushman, M. L. (2011). Organizational ambidexterity in action: How managers explore and exploit. California Management Review, 53(4), 5-22. https://doi.org/10.1525/cmr.2011.53.4.5 
O'Reilly III, C. A., \& Tushman, M. L. (2013). Organizational ambidexterity: Past, present, and future. Academy of Management Perspectives, 27(4), 324-338. https://doi.org/10.5465/amp.2013.0025

Oberer, B., \& Erkollar, A. (2018). Leadership 4.0: Digital Leaders in the Age of Industry 4.0. International Journal of Organizational Leadership. https://doi.org/10.33844/ijol.2018. 60332

Pallant, J. (2007). SPSS Survival Manual 3rd Edition. New York: McGraw Hill.

Pearce, D. L. (2013). Implementing Innovation with Ambidextrous Leadership in Small and Medium Enterprises. Fisher Digital Publication, New York.

Popadiuk, S., Luz, A. R. S., \& Kretschmer, C. (2018). Dynamic capabilities and ambidexterity: how are these concepts related?. Revista de Administração Contemporânea, 22(5), 639-660. https://doi.org/10.1590/1982-7849rac2018180135

Raelin, J. A. (Ed.). (2016). Leadership-as-practice: Theory and application. Routledge. New York and London

Rizvi, M. (2017, March 22). Wheel of Fortune favours Dubai. Khaleejtimes. Retrieved from https://www.khaleejtimes.com/business/corporate/wheel-of-fortune-favours-dubai.

Rogers, D. L. (2016). The digital transformation playbook: Rethink your business for the digital age. Columbia University Press, New York.

Roldán, J. L., \& Sánchez-Franco, M. J. (2012). Variance-based structural equation modeling: Guidelines for using partial least squares in information systems research. In Research Methodologies, Innovations and Philosophies in Software Systems Engineering and Information Systems (pp. 193-221). IGI Global. https://doi.org/10.4018/978-1-4666-0179-6.ch010

Sainger, G. (2018). Leadership in Digital Age: A Study on the Role of Leader in this Era of Digital Transformation. International Journal on Leadership, 6(1), 1.

Sarstedt, M., Wilczynski, P., \& Melewar, T. C. (2013). Measuring reputation in global markets-A comparison of reputation measures' convergent and criterion validities. Journal of World Business, 48(3), 329-339. https://doi.org/10.1016/j.jwb.2012.07.017

Schadler, T., Fenwick, N., Gill, M., Cazalet, A., \& Hartig, K (2017). The Digital Business Imperative. Forrester. Retrieved from https://www.forrester.com/report/ The+Digital+Business+Imperative/-/E-RES115784.

Singapore Economic Development Board. (2020, August 19). Ride the Wave of Asian Growth. Retrieved from https://www.edb.gov.sg/en/our-industries/industries-and-keyactivities/headquarters.html.

Solis, B., and Syzmanski, J., (2016). The Race Against Digital Darwinism: Six Stages of Digital Transformation. Altimeter Group.

Sow, M., \& Aborbie, S. (2018). Impact of leadership on digital transformation. Business and Economic Research, 8(3), 139-148. https://doi.org/10.5296/ber.v8i3.13368

Statista Research Department. (2021, March 29). APAC: Mobile internet user penetration 20182025. Retrieved from https:/www.statista.com/statistics/201232/forecast-of-mobileinternet-penetration-in-asia-pacific/.

Steele, C., Allen, L., \& Watkins, A. (2019). The ethical use of customer data in a digital economy. KPMG. Retrieved from https://home.kpmg/content/dam/kpmg/uk/pdf/2019/04/ethicaluse-of-customer-data.pdf.

Svahn, F., Mathiassen, L., \& Lindgren, R. (2017). Embracing Digital Innovation in Incumbent Firms: How Volvo Cars Managed Competing Concerns. MIS Quarterly, 41(1). https://doi.org/10.25300/misq/2017/41.1.12 
Swift, M., \& Lange, D. (2018). Digital Leadership in Asia Pacific. Korn Ferry Institute. Retrieved from https://focus.kornferry.com/wp-content/uploads/2018/04/Korn-Ferry-Digitalleadership-in-Asia-Pacific.pdf.

Tan, A. (2020). IT Priorities: 2020: APAC. Tech Target. Retrieved from https://www.computerweekly.com/ehandbook/IT-Priorities-2020-APAC.

Takle, J. (2018). Ambidextrous Leadership - transformational skills for a digital age. Retrieved from https://www.linkedin.com/pulse/ambidextrous-leadership-transforming-banksdigital-age-jeremy-takle.

Tannou, M., \& Westerman, G. (2012). Governance: a central component of successful digital transformation. MIT Center for Digital Business and Capgemini Consulting, London.

Tardieu, H., Daly, D., Esteban-Lauzán, J., Hall, J., \& Miller, G. (2020). Leadership-What Is Required of Leaders and Leadership to Achieve Digital Success?. In Deliberately Digital (pp. 95-105). Springer, Cham. https://doi.org/10.1007/978-3-030-37955-1_11

Teece, D. J. (2007). Explicating dynamic capabilities: the nature and microfoundations of (sustainable) enterprise performance. Strategic Management Journal, 28(13), 13191350. https://doi.org/10.1002/smj.640

Teece, D. J. (2009). Dynamic capabilities and strategic management: Organizing for innovation and growth. Oxford University Press on Demand, New York.

Teece, D. J. (2014). The foundations of enterprise performance: Dynamic and ordinary capabilities in an (economic) theory of firms. Academy of Management Perspectives, 28(4), 328-352. https://doi.org/10.5465/amp.2013.0116

Teece, D. J., \& Linden, G. (2017). Business models, value capture, and the digital enterprise. Journal of Organization Design, 6(1), 1-14. https://doi.org/10.1002/smj.640

Tong, J. (2017). Key components of digital governance in organisations. Retrieved from https://www.joshtong.io/blog/2017/11/14/key-components-of-digital-governance-inorganizations.

Tushman, M. L., \& O’Reilly, C. A. (1996). Ambidextrous Organizations: Managing Evolutionary and Revolutionary Change. California Management Review, 38(4), 829. https://doi.org/10.2307/41165852https://doi.org/10.2307/41165852

Valentine, E., \& Stewart, G. (2015, January). Enterprise business technology governance: Three competencies to build board digital leadership capability. In 2015 48th Hawaii International Conference on System Sciences (pp. 4513-4522). IEEE. https://doi.org/10.1109/hicss.2015.539

Vey, K., Fandel-Meyer, T., Zipp, J. S., \& Schneider, C. (2017). Learning \& development in times of digital transformation: Facilitating a culture of change and innovation. International Journal of Advanced Corporate Learning (iJAC), 10(1), 22-32. https://doi.org/10.3991/ijac.v10i1.6334

Vial, G. (2019). Understanding digital transformation: A review and a research agenda. The Journal of Strategic Information Systems, 28(2), 118-144. https://doi.org/10.1016 /j.jsis.2019.01.003

Warner, K. S., \& Wäger, M. (2019). Building dynamic capabilities for digital transformation: An ongoing process of strategic renewal. Long Range Planning, 52(3), 326-349. https://doi.org/10.1016/j.lrp.2018.12.001

Welchman, L. (2015). Managing chaos: Digital governance by design. Rosenfeld Media.

Werts, C. E., Rock, D. R., Linn, R. L., \& Joreskog, K. G. (1978). A general method of estimating the reliability of a composite. Educational and Psychological Measurement, 38(4), 933-938. https://doi.org/10.1177/001316447803800412 
Westerman, G., Bonnet, D., \& McAfee, A. (2014a). Leading digital: Turning technology into business transformation. Harvard Business Press, USA.

Westerman, G., Bonnet, D., \& McAfee, A. (2014b). The nine elements of digital transformation. MIT Sloan Management Review, 55(3), 1-6.

World Economic Forum (2018). The Digital Enterprise: Moving from experimentation to transformation. World Economic Forum in collaboration with Bain and Company. Retrieved from: http://www3.weforum.org/docs/Media/47538_Digital\%20Enterprise_

Moving_Experimentation_Transformation_report_2018\%20-\%20final\%20(2).pdf

Wrede, M., Velamuri, V. K., \& Dauth, T. (2020). Top managers in the digital age: Exploring the role and practices of top managers in firms' digital transformation. Managerial and Decision Economics. https://doi.org/10.1002/mde.3202

Yokoi, T., Shan, J., Wade, M., \& Macaulay, J. (2019). Digital Vortex 2019: Continuous and Connected Change.

Zeike, S., Bradbury, K., Lindert, L., \& Pfaff, H. (2019). Digital leadership skills and associations with psychological well-being. International Journal of Environmental Research and Public Health, 16(14), 2628. https://doi.org/10.3390/ijerph16142628

Zhang, X. A., Cao, Q., \& Tjosvold, D. (2011). Linking transformational leadership and team performance: A conflict management approach. Journal of Management Studies, 48(7), 1586-1611. https://doi.org/10.1111/j.1467-6486.2010.00974.x

\section{Appendix}

\section{Constructs and Measures}

Summary of proposed indicators and their independent variables, as advised by past studies and journal articles.

\begin{tabular}{|c|c|c|c|}
\hline QNo & Indicator & Literature & Independent Variable \\
\hline LA1 & Digital visionary & \multirow{7}{*}{$\begin{array}{l}\text { (Della Corte, Del Gaudio, \& Sepe, 2019; } \\
\text { Cullen, Hui, \& Kittle, 2019; Larjovuori, } \\
\text { Bordi, \& Heikkilä-Tammi, 2018; Swift \& } \\
\text { Lange, 2018; Neubauer, Tarling, \& Wade, } \\
\text { 2017; Heneghan, Snyder, \& Symons, 2017; } \\
\text { Deloitte, 2016) }\end{array}$} & \multirow{7}{*}{$\begin{array}{l}\text { Leadership Attributes } \\
\text { (LA) }\end{array}$} \\
\hline LA2 & Smart risk taker & & \\
\hline LA3 & Foster innovation & & \\
\hline LA4 & Agility & & \\
\hline LA5 & Tolerance of ambiguity & & \\
\hline LA6 & Natural collaborator & & \\
\hline LA7 & Builds digital talent & & \\
\hline SP1 & $\begin{array}{l}\text { Prioritise new business } \\
\text { models }\end{array}$ & \multirow{4}{*}{$\begin{array}{l}\text { (Schadler, Fenwick, Gill, Cazalet, \& } \\
\text { Hartig, 2017; Popadiuk et al., 2018; } \\
\text { Gottlieb \& Willmott, 2014) }\end{array}$} & \multirow{4}{*}{ Strategic Priorities (SP) } \\
\hline SP2 & Build competitive advantage & & \\
\hline SP3 & Keep pace with competitors & & \\
\hline $\mathrm{SP} 4$ & Cost management & & \\
\hline & & & \\
\hline
\end{tabular}




\begin{tabular}{|c|c|c|c|}
\hline QNo & Indicator & Literature & Independent Variable \\
\hline OFA1 & $\begin{array}{l}\text { Diversify business models } \\
\text { through creative } \\
\text { partnerships }\end{array}$ & \multirow{6}{*}{$\begin{array}{l}\text { (World Economic Forum, 2018; . Finzi, } \\
\text { Firth, \& Lipton, 2018; Fenwick \& } \\
\text { Schadler, 2018; De la Boutetière, } \\
\text { Montagner, \& Reich, 2018; Geissbauer, } \\
\text { Vedso, \& Schrauf, 2016; Westerman, } \\
\text { Bonnet, \& McAfee, 2014a, 2014b) }\end{array}$} & \multirow{6}{*}{$\begin{array}{l}\text { Organisational Focus } \\
\text { Areas (OFA) for } \\
\text { Exploration }\end{array}$} \\
\hline OFA2 & $\begin{array}{l}\text { Facilitate data sharing and } \\
\text { data analytics }\end{array}$ & & \\
\hline OFA3 & $\begin{array}{l}\text { Adopt new platforms to } \\
\text { meet new business } \\
\text { challenges }\end{array}$ & & \\
\hline OFA4 & $\begin{array}{l}\text { Identify the roles and } \\
\text { stakeholder partnerships in } \\
\text { business value chain }\end{array}$ & & \\
\hline OFA5 & $\begin{array}{l}\text { Establish digital teams to } \\
\text { foster digital innovation }\end{array}$ & & \\
\hline OFA6 & $\begin{array}{l}\text { Empower employees to } \\
\text { adopt digital technologies }\end{array}$ & & \\
\hline DG1 & Regulatory compliance & \multirow{5}{*}{$\begin{array}{l}\text { (Bongiorno et al., 2018; Solis, 2016; Hyek } \\
\text { \& Nendick, 2014; Tannou \& Westerman, } \\
\text { 2012; Dykes, 2012) }\end{array}$} & \multirow{5}{*}{$\begin{array}{c}\text { Digital Governance } \\
\text { Practices for Exploitation } \\
\text { (DG) }\end{array}$} \\
\hline DG2 & Cyber security planning & & \\
\hline DG3 & Ethical Data handling & & \\
\hline DG4 & Social media management & & \\
\hline DG5 & Employee collaboration & & \\
\hline EL2 & Clear digital vision & \multirow{7}{*}{$\begin{array}{l}\text { (Della Corte et al., 2019; Kane et al., 2019; } \\
\text { Swift \& Lange, 2018; Popadiuk et al., } \\
\text { 2018; Neubauer, Tarling, \& Wade, 2017; } \\
\text { Heneghan, Snyder, \& Symons, 2017) }\end{array}$} & \multirow{7}{*}{$\begin{array}{l}\text { Benefits of Effective } \\
\text { Digital Leadership }\end{array}$} \\
\hline EL2 & $\begin{array}{l}\text { Adept at aligning business } \\
\text { and IT strategy }\end{array}$ & & \\
\hline EL3 & $\begin{array}{l}\text { Higher focus on innovation } \\
\text { and growth }\end{array}$ & & \\
\hline EL4 & $\begin{array}{l}\text { Aggressive investment in } \\
\text { agile and disruptive } \\
\text { technologies }\end{array}$ & & \\
\hline EL5 & $\begin{array}{l}\text { Builds on stable and secure } \\
\text { infrastructure }\end{array}$ & & \\
\hline EL6 & Builds strategic partnerships & & \\
\hline EL7 & $\begin{array}{l}\text { Nurtured the talent to derive } \\
\text { and deliver digital strategy }\end{array}$ & & \\
\hline
\end{tabular}


Copyright: (c) 2022 authors. This is an open-access article distributed under the terms of the Creative Commons Attribution-NonCommercial 3.0 Australia License, which permits noncommercial use, distribution, and reproduction in any medium, provided the original author and AJIS are credited.

doi: https://doi.org/10.3127/ajis.v26i0.2525

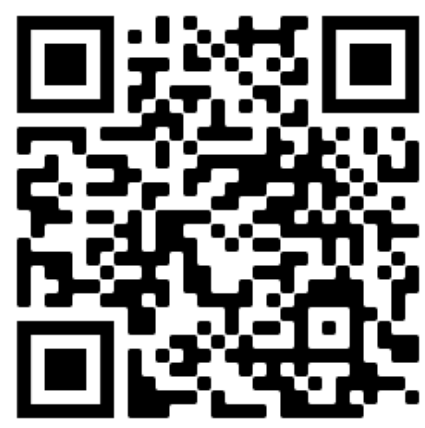

